DIW BERLIN

Discussion

Papers


MMI

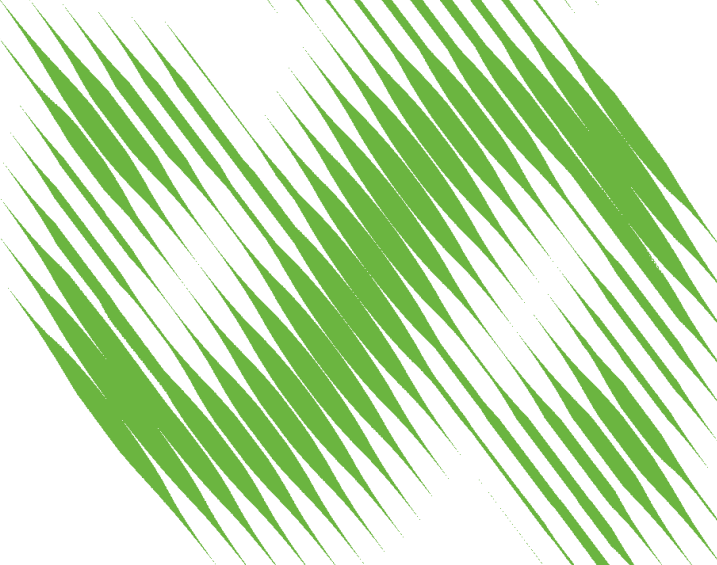

Wind Electricity Subsidies = Windfall Gains for Land Owners?

Evidence from a Feed-In Tariff in Germany 
Opinions expressed in this paper are those of the author(s) and do not necessarily reflect views of the institute.

IMPRESSUM

(C) DIW Berlin, 2016

DIW Berlin

German Institute for Economic Research

Mohrenstr. 58

10117 Berlin

Tel. +49 (30) $89789-0$

Fax +49 (30) $89789-200$

http://www.diw.de

ISSN electronic edition 1619-4535

Papers can be downloaded free of charge from the DIW Berlin website:

http://www.diw.de/discussionpapers

Discussion Papers of DIW Berlin are indexed in RePEc and SSRN:

http://ideas.repec.org/s/diw/diwwpp.html

http://www.ssrn.com/link/DIW-Berlin-German-Inst-Econ-Res.html 


\title{
Wind electricity subsidies = Windfall gains for land owners? Evidence from a feed-in tariff in Germany
}

\author{
Peter Haan* Martin Simmler ${ }^{\dagger}$
}

\begin{abstract}
In 2013, around 121 billion US-Dollar were spend worldwide to promote the investment into renewable energy sources. The most prominent support scheme employed is a feed-in tariff, which guarantees a fixed price for electricity produced by renewable energies sources, usually for around 15 years after the installation of the plant. We study the incidence of wind turbine subsidies, due to a feed-in tariff in Germany, into land prices to shed light on who benefits from the subsidies. In order to identify the incidence share we exploit quasi-experimental variation in wind strength across 270 non-urban counties combined with an institutional reform and use an Instrumental Variable estimator based on administrative transaction prices. We find that between 15 and $20 \%$ of expected wind turbine profits are capitalized into land prices. Using the estimated incidence share of $15 \%$, we find that wind turbine subsidies account for roughly $4 \%$ of overall agricultural income of land owners in 2007.
\end{abstract}

JEL Classification: H22, H23, H25, Q28, Q42.

Keywords: Incidence, subsidy, renewable energy, wind turbines, land prices.

*DIW Berlin, Mohrenstrasse 58, 10117 Berlin, Germany, and Freie Universitaet Berlin, Garystrasse 21, 14195 Berlin, Germany. E-mail: phaan@diw.de.

${ }^{\dagger}$ Corresponding author: University of Oxford Centre for Business Taxation, Park End Street, OX1 1HP, Oxford, UK, and DIW Berlin. Tel: +44 1865 614845. E-mail: martin.simmler@sbs.ox.ac.uk. 


\section{Introduction}

Most countries subsidize investment into renewable energy sources (RES) as increasing the usage of RES for electricity production is seen as key to alleviate the trend in global warming in recent decades. Taking together all the various support schemes around the world, the International Energy Agency estimates that around US\$ 121 billion (100 billion euros) were spent in 2013 to promote green energy (International Energy Agency (2014) ) 11 Spending was in particularly high in the European member states, coming to a total of 40 billion euros (Alberici et al. (2014)). These enormous amounts raise concerns about the distributional consequences and the efficiency of the subsidies. In particular it is of central importance to understand who receives the subsidies. Is it the investor; and consequently does the subsidy ensure that green electricity plants are profitable? Or to what extend do other market participants such as, for example land owners - benefit from the subsidy as windfall gains? The aim of this paper is to provide empirical evidence on this incidence question. To identify the incidence share we exploit quasi-experimental variation in wind strength combined with an institutional reform and use an Instrumental Variable estimator based on administrative transaction prices.

In more detail, in the analysis, we focus on the incidence effect of onshore wind turbine subsidies in Germany. The incidence effects are studied in the context of agricultural land prices. In addition we analyse the consequences of the subsidy on agricultural land owners' income. The setting in Germany is in particular suitable for our analysis. First, RES subsidies are important. In 2012, about 12 billion euros were spent on these subsidies, the rough equivalent of $20 \%$ of Germany's tax revenue on corporate profits. Second, Germany uses a very common policy measure to foster the investment into RES, which is a feed-in tariff. This support scheme has now been introduced in over 60 countries (Requate (2014)) $\mathrm{L}^{2}$ The central mechanism is a guarantee for a fixed wholesale price for electricity produced by RES for usually 15 to 20 years after the installation of the plant. Germany was on of the first countries to introduce this rule when it adopted the Renewable Energy Act (REA) in 2000. Third, descriptive evidence based on aggregate statistics suggests that the REA had a sizeable impact on the energy market. Following the introduction of the REA, electricity produced by RES as a share of overall electricity consumption increased

\footnotetext{
${ }^{1}$ The estimate bases on a survey of established national policies and of deployment of new capacity by the IEA.

${ }^{2}$ Other measures include for example investment grants, quotes and tenders. See Klessmann et al. (2011) for an overview of measures used by different EU countries.
} 
from $6.2 \%$ in 2000 to $23.7 \%$ in 2012 . More than half of the overall electricity generated by RES came from onshore wind turbines ${ }^{3}$ Finally, land owners and investors are likely to be the main beneficiaries of the subsidy for wind turbines as there is no labour involved in the electricity generation using wind turbines.

In order to empirically evaluate the incidence of the subsidy we exploit quasiexperimental variation related to large regional variation in wind strength in combination with the introduction of the REA. In the empirical specification we estimate the effect of the potential future income streams related to wind turbines in a particular county on the average land price in that county. The specification is motivated by Titman's work on the price of vacant land under uncertainty (Titman, 1985) which suggests that the price for each field on which a wind turbine can potentially be built increases with the subsidy.

Our identification strategy allows to estimate the causal effect of the potential future income stream of wind turbines on the land price. In particular, we use an Instrumental Variable estimator and investigate to which extent wind turbine investors receive the subsidy and to which extend the subsidy affects transaction prices for agricultural land and is therefore passed through to land owners. ${ }^{4}$ To ensure unbiased coefficients it is crucial to account for the measurement error in the expected potential future income streams, which have to be modelled as they are not observed. Therefore, we instrument the net present value of the potential future income streams generated by wind turbines in a particular county using regional variation in wind strength across over 270 non-urban counties in combination with the introduction of the REA. Then we estimate the effect on the average land price in the counties.

The results suggest that on average between 15 and $20 \%$ of expected wind turbine profits are capitalized into land prices. The results are robust across a wide range of specifications. In particular, they are not sensitive to the inclusion of different regional time trends or if we account for spatial dependence of land prices. Based on an investors' costs share of roughly 50\%, our findings suggest that on average between 7.5 and $10 \%$ of the subsidy are captured in land prices. The estimated incidence share translates - based on 2010 values - into capitalized

\footnotetext{
${ }^{3}$ Source: Federal Ministry for Economics and Energy 2015, available online at http://www.erneuerbare-energien.de/EE/Redaktion/DE/Downloads/zeitreihen-zur-entwicklungder-erneuerbaren-energien-in-deutschland-1990-2014.pdf?__blob=publicationFile\&v=4, last accessed: $17 / 12 / 2015$

${ }^{4} \mathrm{We}$ focus on agricultural land as this is the main building ground for wind turbines due to a required minimum distance to population areas.
} 
wind turbine subsidies of 4,400 euros per hectare of land or $27 \%$ of the average land price per hectare. Using the estimated incidence share of $15 \%$ and taking into account the characteristics of the German agricultural land market (e.g. share of sold and leased land and amount of sold land every year), we calculate that wind turbine subsidies increase overall agricultural income of land owners by about $4 \%$. We validate the increase in agricultural income as well as our estimated incidence share by using a different data set, namely agricultural income tax data between 1998 and 2007. Using a simple fixed-effects regression analysis at the county level, we show that agricultural income observed in the tax data rises by our calculated additional taxable income resulting from wind turbine subsidies between 1998 and 2007.

Our paper contributes to the prior literature in several ways. First, we estimate the incidence of a subsidy for wind energy into agricultural land prices. In general the production of wind energy is unrelated to the agricultural value of land, but has a measurable impact on agricultural land price. In quantitative terms, the estimated incidence share is at the lower end of estimates for agricultural subsidies. $5^{5}$ Kirwan (2009) estimates for the US an incidence share of 25\%. Hendricks et al. (2012) suggests that the long run incidence in the US may be up to $40 \%$ as inertia in farmland rental rates and different types of tenancy agreements are likely to have biased prior estimates. This is similar to what has been found by Roberts et al. (2003). Ciaian and Kancs (2012) report that in the OECD countries around $20 \%$ of agricultural subsidies are reaped by land owners. Most comparable to our study is the work by Breustedt and Habermann (2011). They estimate an incidence share of $38 \%$ for agricultural subsidies for one region in Germany, namely the state of Lower Saxony. $]^{6}$

Second, we add to the literature that quantifies the distributional impact of environmental subsidies. Fullerton (2009) discusses six ways in which environmental policies (mainly taxation) may have distributional impact, which are all likely to be

\footnotetext{
${ }^{5}$ Similar results as for agricultural subsidies have been found for the incidence of the corporate income tax in the US (Suárez Serrato and Zidar, 2014).

${ }^{6}$ We suggest future demand to be the reason for the incidence share for RES subsidies to be lower than for agricultural subsidies but larger than zero. Appendix B shows that even with excess supply of land today land owners reap a seizable share of profits today if demand is expected to be high in the future. This is similar to the argument made by Sallee (2011), who analyses a subsidy for a new technology as well, hybrid cars, and finds that, despite a current excess demand, the entire surplus of the subsidy is reaped by the car buyers. Sallee suggests that manufacturers are not willing to increase the price due to the subsidy as this would hamper future demand. This suggests that the incidence for subsidies for established products is determined by the current market structure (e.g. Poterba (1996); Besley and Rosen (1999); Carbonnier (2007); Kirwan (2009)) and for new products by the expected market structure.
} 
regressive. The empirical literature has confirmed this presumption for environmental taxes (Parry (2004); Metcalf (1999); Hassett et al. (2009); Grainger and Kolstad (2010)). The driving force behind the distributional impact of a carbon tax seem to be fuel and electricity use (Hassett et al. (2009)), or more precisely the fact that polluting goods are mostly energy intensive and account for a large share of the budget spend by low income households (Grainger and Kolstad (2010)). Metcalf (1999) suggests targeted tax cuts to make the policy distributionally neutral. The change in land prices is of minor importance in these studies as environmental taxes decrease pollution mainly due to abatement technologies. They thus do not consider renewable energies, which are location specific and thus likely to have distributional impact by changing land prices. More closely connected to our work is the study by Groesche and Schroeder (2014); they focus on photovoltaic plants on owner occupied houses and find that the German REA is mildly regressive.

Finally, our results add to the literature that discusses the efficiency of different policy instruments to promote renewable energies (e.g. Menanteau et al. (2003); Haas et al. (2011); Requate (2014)). Whether a price-based (such as a feedin tariff) or a quantity based system (such as tradable green electricity certificates or quotes) should be preferred to foster investment into RES is often evaluated according to three dimensions: costs, installed capacity and technological development (see Menanteau et al. (2003)). Different distributional implications are not discussed although they are important and likely to differ.

The outline of the paper is as follows. Section two describes the relevant institutions and in particular the REA. The data is presented in section three, followed by the methodology in section four. Results on the incidence share are presented in section five, and on the distributional consequences of the wind turbine subsidies in section six. Section seven concludes.

\section{Institutional Background}

To alleviate the increase in global warming and to increase the share of RES to $20 \%$ in 2020 as agreed in the Kyoto Protocol and the Lisbon program, Germany introduced a technology specific feed-in tariff with the adoption of the Renewable Energy Act (REA) in 2000.7 This support scheme for RES seems to be the most

\footnotetext{
7 Eichner and Runkel $(2014)$ provide a rational for why countries subsidize renewable energy production instead of only taxing pollution. They study the optimal choice of the two in a multicountry, two-sector (clean and dirty production) framework with capital mobility and find that
} 
prominent measure in the world as it has by now been adopted in over 60 countries (Requate (2014)). The REA in Germany replaced the Electricity Feed-in Act (EFA) and thus reduced investors' risk in two important dimensions. First, with respect to the wholesale price for energy, and second with respect to the length of time for which the price is paid. Under the EFA, which was a non technology specific feed-in tariff, the wholesale price for electricity was $90 \%$ of the end-consumer price and was only paid for as long as the law was in effect. Under the REA, a fixed technology-specific wholesale price is guaranteed for 20 years after the installation of the plant

The REA obliges utilities to accept the feed-in of green electricity from independent producers into their grid and to remunerate it at a given price. The costs of the subsidy, which equal the difference between the wholesale market price of electricity and the feed-in tariff, are born by almost all electricity consumers 8 They pay a share of their electricity bill into a fund from which the costs of the utilities are reimbursed. If the costs of the subsidy increase, the share of the electricity bill is adjusted. In 2013, the direct costs of the subsidy amount to roughly $20 \%$ of the average electricity bill (Neuhoff et al. (2012)).

The feed-in tariff guaranteed by the REA depends on the RES used for the production 9 The wholesale price for wind electricity over the life time of the plant is determined by three parameters, two tariffs (high and low) and a parameter which determines the duration of the high tariff 10 The two tariffs decreased relatively steadily from 9.1 and 6.19 cent per kWh in 2000 to 9.02 and 4.92 cent per kWh in 2012 due to reforms and degression rates included in the REA (see Table 1). The parameter governing the duration of the high tariff increased from 0.75 to 0.85 between the years 2005 and 2008. The most significant change in the feedin tariff after its introduction was implemented with a reform of the REA in 2009. Unproductive wind turbines with less than $60 \%$ of the reference plant return did not longer receive the subsidy. This implied a partial abolition of the promotion scheme

subsidizing RES reduces the overall distortion of the tax-subsidy system.

${ }^{8}$ Reductions are granted to energy intensive companies. This has been investigated by the European Commission and has been found to be in line with state aid rules (http://europa.eu/rapid/press-release_IP-14-2122_en.htm).

${ }^{9}$ For photovoltaics the tariff according to the REA 2000 was the highest with 48.1 cent per $\mathrm{kWh}$, for water energy it amounted to 7.67 cent per $\mathrm{kWh}$.

${ }^{10}$ This period is at least 5 years but in most cases considerably longer as it is extended if the wind turbine has a lower productivity compared to a reference plant defined in the law. For the reference plant defined in the law, the first, higher tariff is for example paid 16 years. See Appendix $\mathrm{C}$ for further details. 
for certain areas. Despite the reduction in the feed-in tariff, the return of newly built wind power plants increased over time remarkably due to to the technological development of wind turbines, see Figure 1,11

Table 1: Feed-in Tariff for Wind Energy

\begin{tabular}{|c|c|c|c|c|c|}
\hline Year & $\begin{array}{c}\text { Tariff } \\
1\end{array}$ & $\begin{array}{l}\text { Factor for time period } \\
\text { calculation for tariff } 1\end{array}$ & $\begin{array}{c}\text { Tariff } \\
2\end{array}$ & $\begin{array}{l}\text { Minimum } \\
\text { return }\end{array}$ & $\begin{array}{l}\text { Guaranteed time } \\
\text { period in years }\end{array}$ \\
\hline 1991-1999 & \multicolumn{4}{|c|}{$90 \%$ of the consumer electricity price } & none \\
\hline 2000 & 9.10 & 0.75 & 6.19 & & 20 \\
\hline 2001 & 9.10 & 0.75 & 6.19 & & 20 \\
\hline 2002 & 8.96 & 0.75 & 6.10 & & 20 \\
\hline 2003 & 8.83 & 0.75 & 6.01 & & 20 \\
\hline 2004 & 8.70 & 0.75 & 5.92 & & 20 \\
\hline 2005 & 8.70 & 0.85 & 5.50 & & 20 \\
\hline 2006 & 8.70 & 0.85 & 5.50 & & 20 \\
\hline 2007 & 8.70 & 0.85 & 5.50 & & 20 \\
\hline 2008 & 8.53 & 0.85 & 5.39 & & 20 \\
\hline 2009 & 9.2 & 0.75 & 5.02 & $60 \%$ & 20 \\
\hline 2010 & 9.2 & 0.75 & 5.02 & $60 \%$ & 20 \\
\hline 2011 & 9.11 & 0.75 & 4.97 & $60 \%$ & 20 \\
\hline 2012 & 9.02 & 0.75 & 4.92 & $60 \%$ & 20 \\
\hline
\end{tabular}

\section{$3 \quad$ Data and Descriptive Statistics}

To investigate the effect of the subsidy for wind electricity on transaction prices for agricultural land, we use three different sets of variables in our empirical analysis: i) transaction prices for agricultural land, ii) the net present value of expected wind turbines profits, and iii), variables that capture the return of agricultural land and the demand for agricultural products. Since transaction prices are only observed on the county level, we aggregate all other variables and use averages on the county level.

Transaction prices: Our sample for the empirical analysis includes all nonurban counties in Germany for which transaction prices are available between 1997 and 2012 and without any changes in their administrative boundaries ${ }^{12}$ The in-

\footnotetext{
${ }^{11}$ The average installed capacity of a single wind turbine doubled between 1995 and 2010, mainly related to higher plant size and larger rotor calibres (see Figure A.1). See Johnstone et al. (2010) for an empirical analysis on the impact of RES support schemes on technological development.

${ }^{12}$ Counties in Thuringia are only included from 2004 onwards due to missing information before
} 
Figure 1: Evolution Wind Turbine Profitability

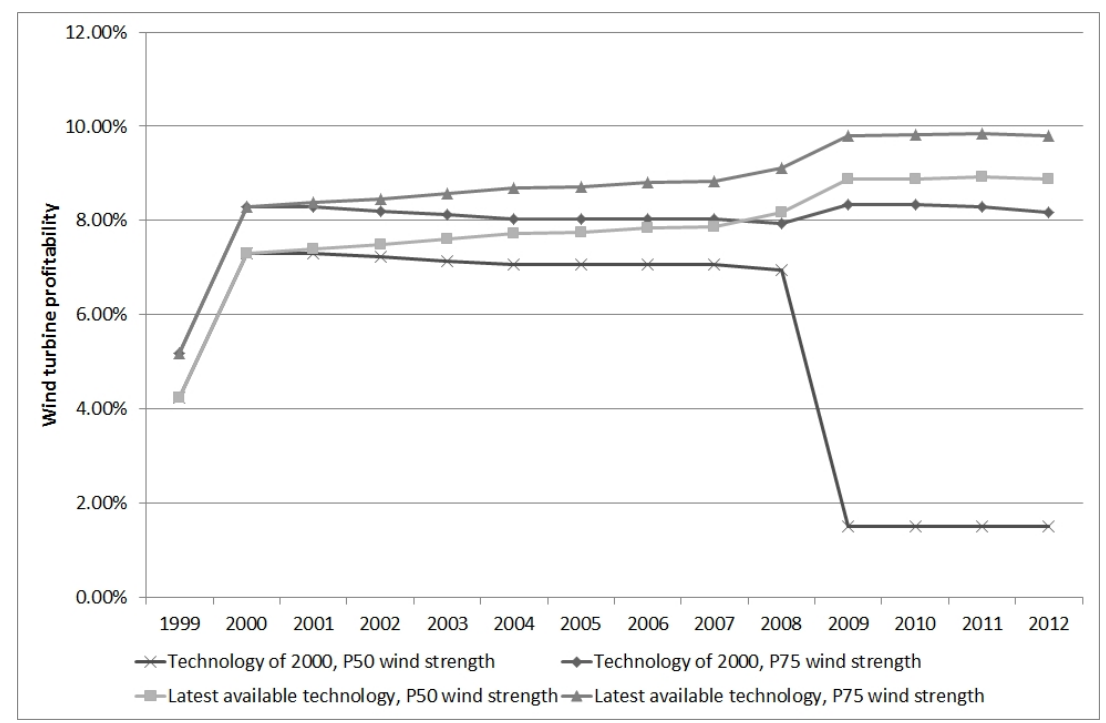

Notes: Evolution of expected wind turbine profitability for two different average wind strengths are shown. P50 stands for the median, P75 for the 75 th percentile. The profitability of a wind turbine in a current year is calculated as expected income over costs using the latest available technology. The latest available technology is based on the average technology of wind turbines built in a current year. For more details on the calculation of expected income and costs see Appendix C.

Source: Author's calculations based on data of the German Weather Service and operator database 1999-2012.

formation on average transaction prices for agricultural land at the county level for the period between 1997 and 2012 are obtained from the publications of the Federal Statistical Offices of the German states. We focus on transaction prices for agricultural land as this is the main building ground for wind turbines due to a required minimum distance to population areas. To ensure that the transaction prices are representative on a county level, we exclude counties for which less than 10 transactions occurred within a year ${ }^{13}$ Thus overall the analysis is based on an unbalanced panel for 1997 to 2012 with around 270 counties and 4,107 county-year observations.14 The counties covered in our sample account for about $80 \%$ of the installed capacity of wind turbines and the number of turbines in Germany (see Table A.1, Appendix A)

Net present value of expected wind turbine profits: The net present value of expected wind turbine profits in one county is constructed in several steps

that time. For the same reasons, counties in Schleswig-Holstein, North Rhine Westphalia and Bavaria are not included for the year 1997. Due to two changes in the administrative boundaries during the time period studied, counties in Sachsen-Anhalt are not in the sample.

${ }^{13}$ Further, we dropped counties in which the absolute value of the growth rate of the transaction price was below the $1 \%$ or above the $99 \%$ percentile to avoid that outliers drive the results.

${ }^{14}$ Results are not significantly different if we use a (un)balanced panel for 1998 to 2010. 
using the following data sources: a) Information on the technological details of all wind turbines in Germany from the operator databas ${ }^{15}$, b) Information on the (1981 to 2000) average wind strength on a square kilometre raster 10 and 80 metre above the ground provided by the German Weather Service ${ }^{16}$, c) information from the financial statements database DAFNE about the financing of wind turbines and the calculation of the depreciation allowances for the turbines, and d) information on the regional share of suitable agricultural land to build wind turbines from the German Enviromental Agency (2013).

We calculate the profits of an average technology wind turbine per hectare for each German county and year ${ }^{17}$ First, we calculate the produced energy of the representative county-year wind turbine using the mean characteristics of wind turbines built in a particular year and the average wind strength in the county. Second, based on the feed-in tariff that applied in a particular year and the expected electricity generated of the plant, we derive the expected income streams and discount them using a discount rate of 3\%.18 Third, expected investment and finance (including equity) costs are deducted. Investment costs are approximated based on installed capacity. The share of bank financing, maturity and interest rate are based on descriptive statistics in DAFNE. Fourth, we derive the expected net present value of wind turbine profits per hectare by dividing profits through the amount of land used. The land usage accounts for the baseplate as well as the minimum distance to the next wind turbine which is determined by law. We approximate the required minimum distance based on the published ratio of installed capacity to minimum distance, which is 6 hectare per MW German Enviromental Agency (2013)). Finally, we scale the county-year representative net present value of profits per hectare with the regional share of suitable land to build wind turbines published by the German Enviromental Agency (2013) to account for the fact that turbines

\footnotetext{
${ }^{15}$ Although the database is private (http://www.betreiber-datenbasis.de/) it covers all wind turbines in Germany. To assess the representativeness we compared the reported number of plants and installed capacity with information published by the network operators (https://www.netztransparenz.de/de/Anlagenstammdaten.htm). The latter is a publicly available database but contains no information on wind turbine's technology.

${ }^{16}$ We mapped the data to German county level by first mapping it to the municipality level and then constructing a weighted average on the county level using the agricultural land within the municipalities as weighting factor.

${ }^{17}$ A detailed description can be found in Appendix C. Descriptive statistics based on wind turbine firms are reported in Appendix D.

${ }^{18}$ For wind turbines built before the REA was introduced we assume that investors expected to receive the guaranteed price of $90 \%$ of the end-consumer price for three years after the installation of the plant, afterwards we assume that investors expected the on average market price for electricity of 3 cent per kWh.
} 
Figure 2: NPV Wind Turbine Profits per Figure 3: NPV Wind Turbine Profits per Hectare in 1998

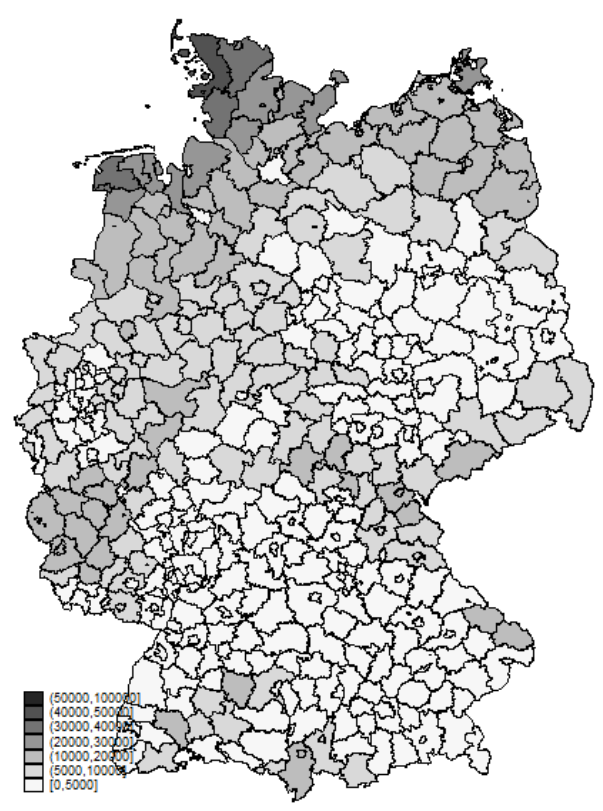

Hectare in 2002

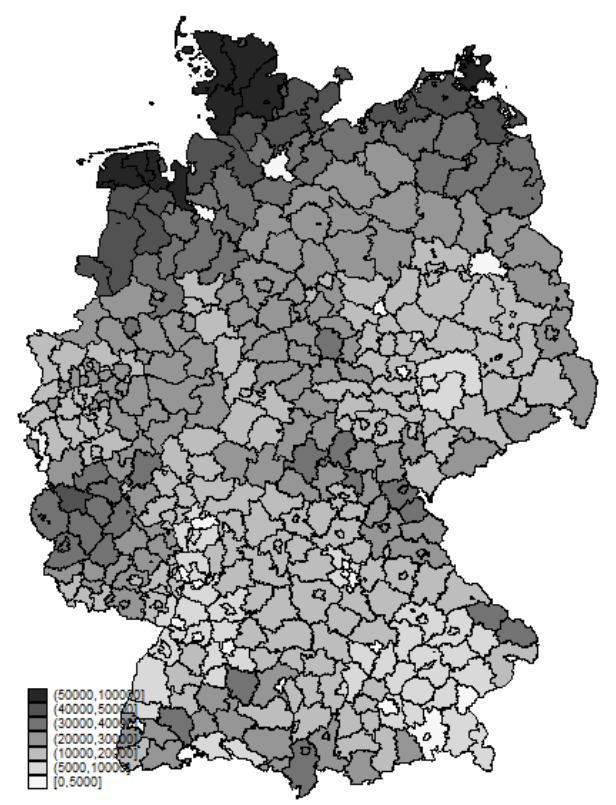

Notes: The net present value of expected wind turbine profits per hectare for each German county in 1998 is shown. For more details see the description in the text. Source: Author's calculations based on data of the German Weather Service and the operator database, 1998.

Notes: The net present value of expected wind turbine profits per hectare for each German county in 2002 is shown. For more details see the description in the text. Source: Author's calculations based on data of the German Weather Service and the operator database, 2002.

cannot legally be built on all agricultural land 19 The resulting net present value of wind turbine profits per hectare in each county in Germany in 1998 and 2002 is shown in Figure 2 and Figure 3, respectively. The figures suggest a remarkable cross-sectional as well as time-series variation due to the introduction of the REA.

Variables capturing the agricultural value of land: In the analysis we include a variety of indicators that determine the price of land in addition to potential profits of wind turbines. The data is provided by the Federal Statistical Office. In particular we include: share of farmland or of grassland (base category: permanent crop); the share of cereal, root crop or forage crop (base category: trade plants); the harvest per hectare wheat, potatoes and silo corn; and the share of land used by farms with stock breeding. In addition we include variables which capture the impact of urban proximity. Namely, we control for the population and the population density (population divided by area size), the average wage income, the rate of unemployment the average property tax on agricultural land, the average business tax and the property transfer tax within the county. Finally, we include

\footnotetext{
${ }^{19} \mathrm{We}$ take the legal constraint as given, although market participants might have expected changes.
} 
the inverse distance weighted average of the population in neighbouring counties ${ }^{20}$

Descriptive statistics for all variables are shown in Table 2. The average transaction price is 17.100 euros, the expected net present value of wind turbine profits amounts to 21.200 euros per hectare, the expected net present value of wind turbine revenues amounts to 38.900 euros per hectare.

\section{Methodology}

\subsection{Estimation Equation}

In the following we present the empirical strategy for the analysis of the incidence effects of the REA. As mentioned above, we observe land prices per hectare not on the field level but on the county level $j$. Thus we estimate the effect of the net present value of expected profits per hectare $W R_{j, t}$ and the agricultural return $A R_{j, t}$ on the land price $L P_{j, t}$ on the county level; $\omega_{j, t}$ is an i.i.d. distributed error term ${ }^{21}$

$$
L P_{j, t}=a_{j}+\alpha W R_{j, t}+\gamma A R_{j, t}+\omega_{j, t}
$$

For the interpretation of the incidence effect two points are important to note. First, we assume that wind turbines do not affect the agricultural return of land. Thus, investors do not have to compensate land owners for a loss in agricultural production if a turbine is built. This assumption is plausible as the size of the baseplate of a wind turbine is very small. The relationship between profits and the share reaped by land owners is thus independent of the agricultural return, i.e. $W R_{j, t}$ and $A R_{j, t}$ are not correlated.

Second, land prices of suitable fields are affected independent of whether a turbine has been built on a field during our sample period or not. Titman (1985) shows that expectations about future demand, and thus land prices in the future, are

\footnotetext{
${ }^{20}$ In a robustness check, we account also for a potential spatial dependence of agricultural land prices by including the inverse distance weighted average transaction price in neighbouring counties. To address the endogeneity of this variable, we employ an instrumental variable approach. The choice of our instrument follows the approach used for our main explanatory variable.

${ }^{21}$ In order to interpret the coefficient $\alpha$ as the incidence share of the subsidies we focus only on the fraction of land that can be used to build wind turbines when calculating $W R_{j, t}$. As explained in section 3, we observe the regional share of land on which turbines can legally be built: based on this information we adjust the net present value of wind turbine profits per county.
} 
Table 2: Descriptive Statistics

\begin{tabular}{l|cccccc}
\hline Variable & $\mathrm{N}$ & Mean & P25 & P50 & P75 & SD \\
\hline Land price ph in euro & 4,107 & 17,087 & 8,567 & 14,625 & 23,659 & 11393 \\
Land quality (1 to 100) & 4,107 & 70 & 37 & 44 & 52 & 310 \\
Number of transactions & 4,107 & 132 & 62 & 110 & 175 & 95 \\
Total sold land in hectare & 4,037 & 311 & 78 & 153 & 304 & 507 \\
Share total sold land in \% & 4,037 & 0.48 & 0.23 & 0.37 & 0.59 & 0.42 \\
& & & & & & \\
Wind strength 80m above ground in m/s & 4,107 & 5.4 & 5.1 & 5.4 & 5.8 & 0.5 \\
NPV WT profits ph in euro & 4,107 & 21,197 & 9,258 & 20,167 & 30,144 & 15,189 \\
NPV WT revenues ph in euro & 4,107 & 38,897 & 27,079 & 36,699 & 49,792 & 17,333 \\
NPV WT profits ph in euro (built) & 4,107 & 699 & 2 & 167 & 946 & 1,175 \\
& & & & & & \\
Agricultural return & & & & & & \\
Share grassland in \% & 4,107 & 32.9 & 17.3 & 27.3 & 44.8 & 21 \\
Share farmland in \% & 4,107 & 63.9 & 47.9 & 68.9 & 80.4 & 21 \\
Share land cereal \% & 4,107 & 38.5 & 28.8 & 40.3 & 49 & 14.2 \\
Share land root crop \% & 4,107 & 4.2 & 0.5 & 1.8 & 4.7 & 6.2 \\
Share land forage crop in \% & 4,107 & 8.5 & 4.3 & 7.3 & 11.5 & 5.5 \\
Harvest ph wheat in tons & 4,107 & 69 & 62 & 69 & 77 & 12 \\
Harvest ph potatoes in tons & 4,107 & 342 & 295 & 343 & 391 & 80 \\
Harvest ph corn in tons & 4,107 & 431 & 397 & 446 & 481 & 77 \\
Share land farms with stock breeding in \% & 4,107 & 0.7 & 0.6 & 0.8 & 0.8 & 0.2 \\
Biogas plants income ph in euro & 4,107 & 1,149 & 0 & 220 & 1,642 & 1,934 \\
& & & & & & \\
Demand for agricultural products & 4,107 & 11.98 & 11.61 & 11.88 & 12.34 & 0.51 \\
log(Population) & 4,107 & 13.3 & 11.2 & 13.8 & 15.2 & 2.9 \\
log(Distance weighted population) & 4,107 & 5.16 & 2.12 & 3.16 & 5.77 & 5.71 \\
Population density & 4,107 & 2,158 & 1,081 & 1,675 & 2,744 & 1,510 \\
Average wage income per month in euro & 4,107 & 0.07 & 0.04 & 0.06 & 0.08 & 0.05 \\
Unemployment rate & & & & & & \\
Tax variables & 4,107 & 270 & 237 & 293 & 325 & 89 \\
Property tax on agricultural land & 4,107 & 3.6 & 3.5 & 3.5 & 3.5 & 0.3 \\
Property transfer tax & 4,107 & 323 & 315 & 333 & 352 & 70 \\
Local business tax & & & & & & \\
\hline
\end{tabular}

Notes: Property tax on agricultural land is the average multiplier in the county. To derive the tax rate the multiplier has to be multiplied with $6 \%$. Local business tax is the average local business tax multiplier in the county. To derive the tax rate the multiplier has to be multiplied with $0.05 \%$ before 2008 and $0.035 \%$ after 2007 . ph stands for per hectare, NPV for net present value and WT for wind turbine. For further details see text. Source: Author's calculation based on data of the German Weather Service, operator database 1990-2012, Statistik Lokal and Regional 1997-2012, Federal Statistic Office of the Laender 1997-2012. 
included in the land price today. Land owners will ask, therefore, for compensation if they sell their suitable land to non-investors, as the new owner may sell the land to an investor in the future. Since there is only one market price for a particular type of land, the price of land is independent of whether the land is bought by an investor (and thus a turbine is built) or by a non-investor (and no turbine is built). Thus, even if no turbines would have been build in our sample period, $\alpha$ would be larger than zero if land owners expect with a non-zero probability that turbines will be built in the future. For a more formal analysis of this argument see Appendix B.

\subsection{Estimation Strategy}

The main reason why an OLS estimate for the parameter of interest $\alpha$ in equation (1) will be biased is measurement error. ${ }^{22}$ We do not observe the true net present value of expected wind turbine profits per hectare in a county; instead we approximate the expected wind turbine profits with the profits of an average technology wind turbine per hectare in a particular county and year adjusted with the regional share of (legally) suitable land. Therefore, the net present value of expected profits is subject to measurement error which we need to take into account in the estimation. Our specification does, however, not suffer from the endogeneity of the location decision since we do not use the average profits of installed wind turbines and/or the share of land chosen to build wind turbines.

Our identification strategy accounts for the measurement error and allows us to estimate the causal effect of the potential income stream on the land price. In particular, we use an Instrumental Variable estimator and instrument the net present value of the potential future income streams generated by wind turbines in a particular county using regional variation in wind strength across over 270 nonurban counties in combination with the introduction of the REA. In more detail, we use a difference-in-differences (DiD) strategy as an instrument in the first stage. We define the treatment and control groups based on the average wind strength in a county as this is a strong predictor for wind turbine profitability; hence we

\footnotetext{
${ }^{22}$ Another thread to our estimation strategy, which would not only bias the OLS but also any other estimator, is a systematic change in the composition of the transacted land due to wind turbine subsidies. In other words, it is required that wind turbine investors are indifferent between buying agricultural land and leasing it only. If they are not indifferent, the composition of the transacted land would change over time non randomly and thus limit comparability over time. Using the IV strategy as outlined in this section, we assessed whether the number of transactions, the size of sold land and the quality of sold land changed in response to the introduction of the subsidy. We do not find evidence for that. Results are available upon request from the authors.
} 
Figure 4: Average Wind Strength in $\mathrm{m} / \mathrm{s}$ in German Counties

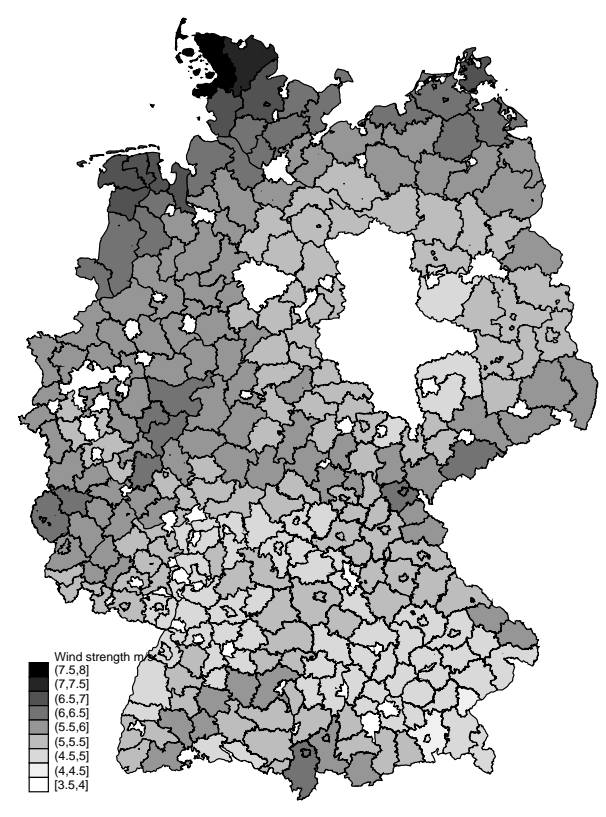

Notes: White counties are not included in the analysis.

Source: Author's calculations based on data of the German Weather Service.

exploit that the treatment counties were affected by the introduction of the REA with a higher intensity than those counties with a low wind strength, i.e. the control counties.

In Figure 4, we document that the wind strength varies substantially between German counties. Although it is clear that the wind strength is in particular high near the coast, it is also much higher in the middle of Germany and higher in the western part of the north compared to the eastern part. This suggests that the variation in wind strength is largely independent of other regional variation in particular between states. This allows us to include linear and quadratic statespecific time trends in the regression to capture any other state specific trends in land prices. Further, it is unlikely that the wind strength is correlated with idiosyncratic county characteristics which are the reason for the measurement error in the net present value of profits. ${ }^{23}$

In one of the main specifications we define counties with wind strength above

\footnotetext{
${ }^{23}$ Examples for idiosyncratic county characteristics are the preference of the population for wind energy (which may pressure politicians and so result in the delayed issuance of building permits), the distribution of population areas or nature protection areas and agricultural land within the county (which affects the share of suitable land within a county) or the density of the electricity network (which is important as the wind turbine investor has to pay for the connection to the grid).
} 
the median as the treatment group and the other counties as control groups ${ }^{24}$ Further, we propose to exploit even more of the variation for our instrument. In an additional specification we construct a treatment intensity variable, which is defined as the average wind strength in a particular county instead of splitting the sample in treatment and control groups. The treatment (intensity) variable is then interacted with a reform dummy for years after the introduction of the REA.

More formally, in the first stage we regress the net present value of expected wind turbines profits in a county $\left(W R_{j, t}\right)$ on the instrument $\left(W S_{j, t} * D(>1999)\right)$, a post-treatment indicator $(D(>1999))$ and the control variables $\left(A R_{j, t}\right)$ which capture the agricultural return of land (see equation (2)). The results of the first stage regression indicate that our instrument is highly relevant and explains roughly $2 / 3$ of the variation in the net present value of wind turbine profits (see Table A.2, Appendix A).

$$
W R_{j, t}=a+a_{1} W S_{j, t}+a_{2} W S_{j, t} * D(>1999)+a_{3} D(>1999)+a_{4} A R_{j, t}+u_{j, t}
$$

In the second stage of our approach we then regress the average transaction price of land on the predicted net present value of wind turbine profits $\left(W \hat{R}_{i, t}\right)$ in the county and the controls.

$$
L P_{j, t}=c+\alpha A R_{j, t}+\alpha_{1} W \hat{P}_{j, t}+\omega_{j, t}
$$

An important underlying assumption for our identification strategy is the common trend between the treatment and the control group. In other words, the transaction prices for land in the treatment and control group should behave similar in the absence of the introduction of the REA. To assess the plausibility of this assumption, Table 3 reports descriptive statistics in 1999 for the treatment and control group based on median wind strength. Further, Figure 5 shows the evolution of land prices between 1998 and 2010 for the two groups ${ }^{25}$

The descriptive statistics for the treatment and control groups suggest differences in the agricultural return of land and in the land usage for the two groups (see Table 3). Regarding population, population density, income, and the local business

\footnotetext{
${ }^{24}$ Our results are not sensitive to this choice. They are almost unchanged when using the mean or the 75 th percentile for the classification instead. Results are available upon request from the authors.

${ }^{25}$ We only include 1998 to 2010, as for 1997, 2011 and 2012 the number of observations is much smaller than for 1998 to 2010 .
} 
Table 3: Descriptive Statistics Treatment and Control Group 1999

\begin{tabular}{|c|c|c|c|c|c|}
\hline \multirow[b]{2}{*}{ Variable } & \multicolumn{2}{|c|}{ Treatment Group } & \multicolumn{2}{|c|}{ Control Group } & \multirow{2}{*}{$\begin{array}{c}\text { p-value } \\
\text { t-test }\end{array}$} \\
\hline & Mean & SD & Mean & SD & \\
\hline Land price ph in euro & 13,786 & 9,586 & 21,348 & 13,097 & 0 \\
\hline Wind strength $80 \mathrm{~m}$ above ground in $\mathrm{m} / \mathrm{s}$ & 5.9 & 0.4 & 5 & 0.3 & 0 \\
\hline Land quality & 42.4 & 9.3 & 48.5 & 10.8 & 0 \\
\hline \multicolumn{6}{|l|}{ Agricultural return: } \\
\hline Share grassland in \% & 38.2 & 23.6 & 29.6 & 19.1 & 0 \\
\hline Share farmland in \% & 59.1 & 23.4 & 66.6 & 19.1 & 0.01 \\
\hline Share land cereal \% & 33.8 & 15 & 37.8 & 11.8 & 0.02 \\
\hline Share land root crop $\%$ & 3.5 & 5.8 & 5.9 & 7.5 & 0.01 \\
\hline Share land forage crop in $\%$ & 9 & 5.9 & 9.5 & 5.9 & 0.48 \\
\hline Harvest ph wheat & 73 & 14 & 65 & 11 & 0 \\
\hline Harvest ph potatos & 328 & 90 & 325 & 61 & 0.73 \\
\hline Harvest ph corn & 437 & 67 & 453 & 61 & 0.04 \\
\hline Share land farms with stock breeding in $\%$ & 0.8 & 0.1 & 0.7 & 0.2 & 0 \\
\hline \multicolumn{6}{|l|}{ Demand for agricultural products: } \\
\hline $\log ($ Population $)$ & 12 & 0.5 & 12 & 0.5 & 0.42 \\
\hline $\log ($ Distance weighted population $)$ & 12.9 & 3 & 14.3 & 2.5 & 0 \\
\hline Population density & 4.74 & 5.41 & 5.79 & 6.24 & 0.15 \\
\hline Average wage income per month in euro & 1,977 & 1,328 & 1,968 & 1,382 & 0.96 \\
\hline Unemployment rate & 0.09 & 0.04 & 0.07 & 0.03 & 0 \\
\hline \multicolumn{6}{|l|}{ Tax variables: } \\
\hline Property tax on agricultural land & 258 & 53 & 294 & 55 & 0 \\
\hline Property transfer tax & 3.5 & 0 & 3.5 & 0 & 1 \\
\hline Local business tax & 327 & 48 & 323 & 40 & 0.45 \\
\hline
\end{tabular}

Notes: Treatment group includes counties with wind strength 80 metre above ground above the median. Control group includes counties with wind strength equal or below the median. Property tax on agricultural land is the average multiplier in the county. To derive the tax rate the multiplier has to be multiplied with $6 \%$. Local business tax is the average local business tax multiplier in the county. To derive the tax rate the multiplier has to be multiplied with $0.05 \%$ before 2008 and $0.035 \%$ after 2007 . ph stands for per hectare. In 1999 the property transfer tax was the same for all states in Germany.

Source: Author's calculation based on German Weather Service, Statistik Lokal and Regional, Federal Statistic Offices of the Laender, 1999. 
Figure 5: Evolution Land Price for Treatment and Control Group

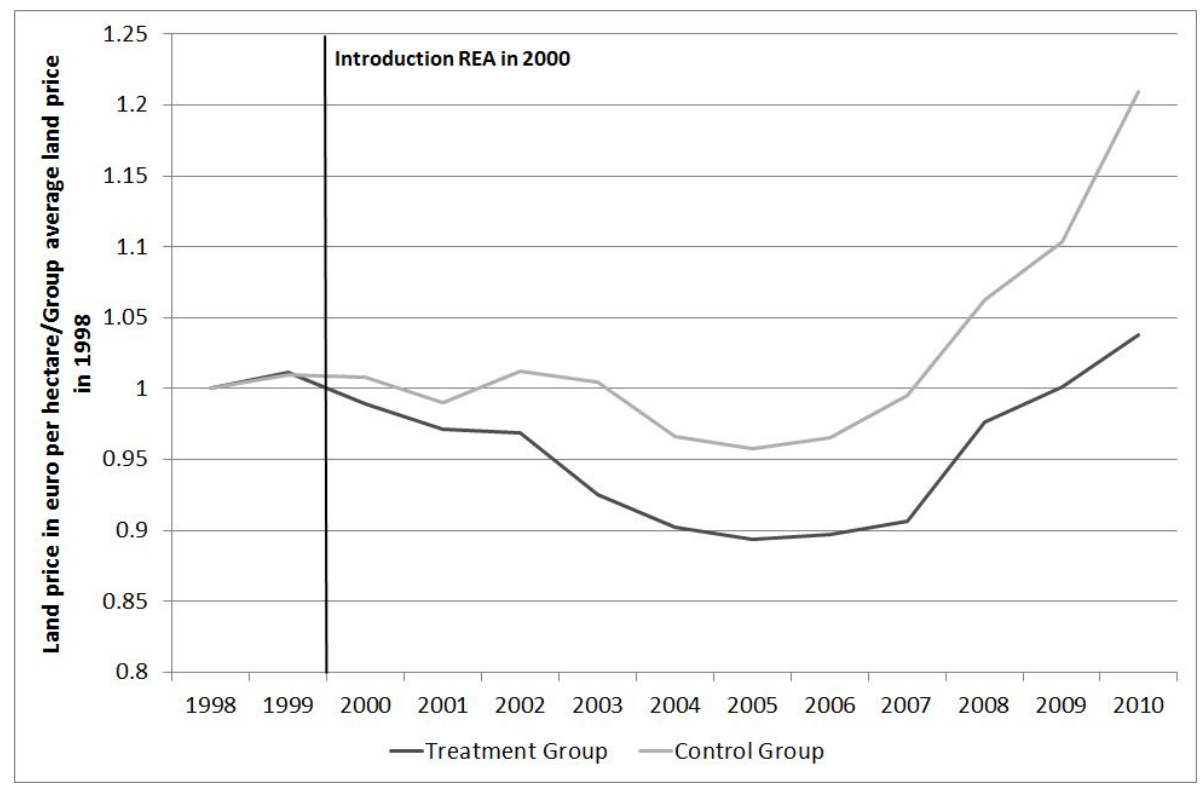

Notes: Average land prices for treatment and control group are shown, normalized by the group mean in 1998. Treatment group includes counties with wind strength 80 meter above ground above the median. Control group includes counties with wind strength equal or below the median.

Source: Author's calculation based on data of the German Weather Service and Federal Statistical Offices of the Laender, 1998-2010.

tax rate no differences are observed. To control for potential differences in the levels we account for county-fixed effects and include in all specifications interaction effects with the agricultural return variables and a dummy for the introduction of the REA; the latter is to control for a different impact of the agricultural return variable on land prices after the the introduction of the REA. Finally, Figure 5 documents a common trend in the land prices before the introduction of the reform.

\section{Estimation Results: Incidence Share}

Main results: We present now the results of our main regression analysis (see Table 4). In the first two columns the OLS estimates with and without control variables are reported. The estimated coefficient is in both specification close to zero and statistically insignificant. As discussed above we suspect the OLS estimates to be biased and the main reason to be measurement error in the net present value of wind turbine profits (NPV WT profits). Column (3) to (6) present the IV results. In column (3) and (4) we use the interaction term between the treatment group based on median wind strength and the reform dummy, in column (5) and (6) the interaction between treatment intensity, e.g. the average wind strength in the 
county, and the reform dummy as an excluded instrument.

Table 4: Main Results

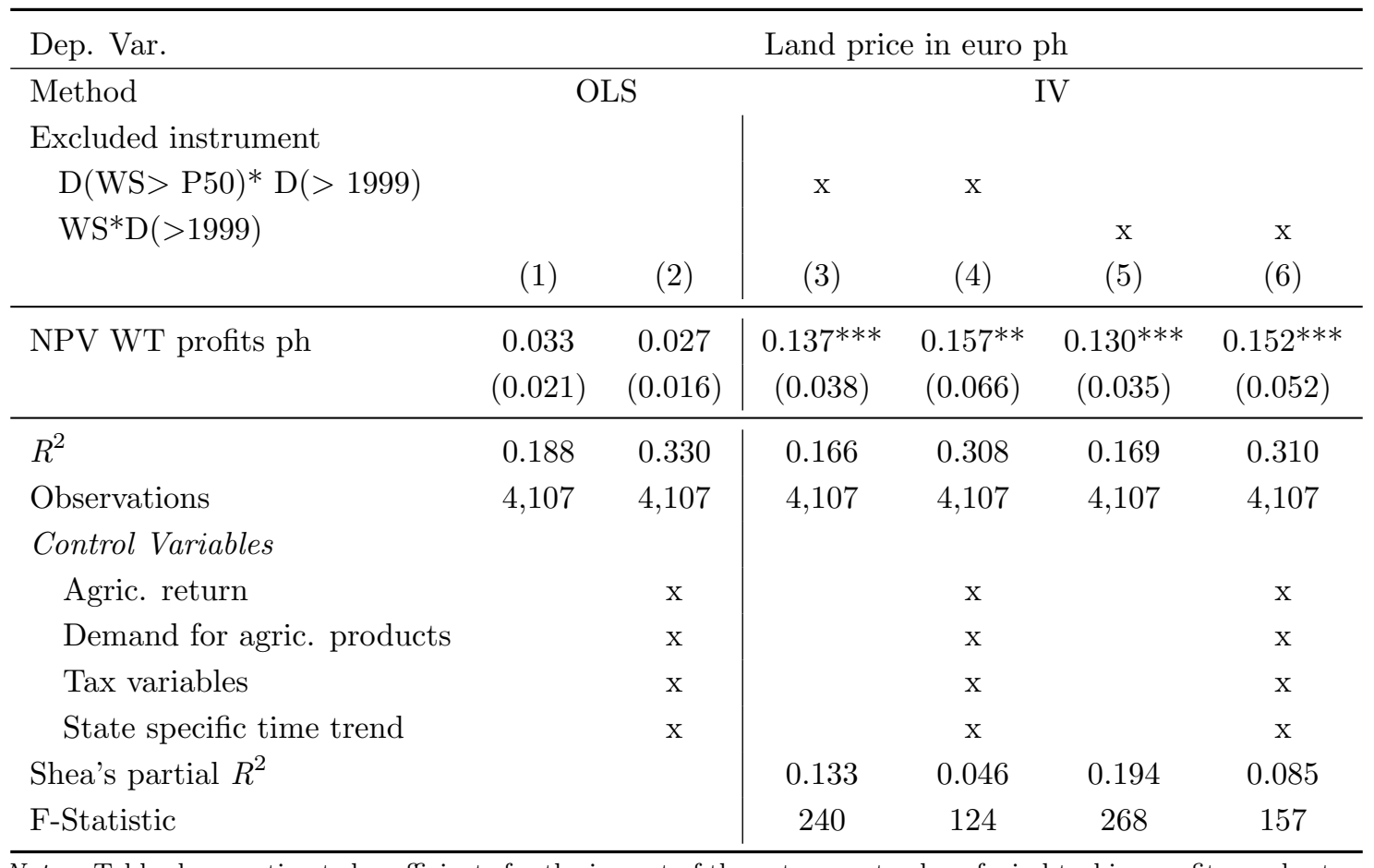

Notes: Table shows estimated coefficients for the impact of the net present value of wind turbine profits per hectare on average land prices. WS stands for wind strength, and NPV WT profits ph for net present value of wind turbine profits per hectare. Column (1) and (2) are OLS estimates, (3) to (6) IV estimates. The excluded instrument in column (3) and (4) is the interaction between a treatment dummy which is one for counties with a wind strength above the median and a reform dummy for years after the introduction of the REA. In column (5) and (6) it is the interaction between the average wind strength $80 \mathrm{~m}$ above ground on the county level and the reform dummy. Each regression includes a full set of county and time dummies (not reported.) Robust standard errors, clustered at the county level, in parentheses. Significance levels: ${ }^{*} \mathrm{p}<0.1,{ }^{* *} \mathrm{p}<0.05,{ }^{* * *} \mathrm{p}<0.01$.

Source: Author's calculation based on data of the German Weather Service, operator Database 1990-2012, Statistik Lokal and Regional 1998-2012, Statistical Offices of the Laender 1997-2012.

The result in our most preferred specification shown in column (6) suggests that an increase of 1 euro in the net present value of wind turbine profits per hectare increases the price for land per hectare by 15 cents. In other words $15 \%$ of the net present value of wind turbine profits are reaped by land owners. The results are not significantly different if we use the treatment dummy instead of the intensity to construct our instrument (column (4)) or if we exclude our set of control variables (column (4)) or both (column (3)). Since profits may only be a small fraction of the overall subsidy paid, we calculate the capitalized amount as a share of the net present value of the expected subsidies. Based on the average costs share of roughly $50 \%$ in our sample (see Table 2 ), the incidence share is $7.5 \%$ when based on expected subsidy payments. Since the costs of wind turbines are mainly fixed costs, the incidence of a marginal increase in wind turbine subsidies by 1 euro is the same as for profits and amounts to 15 cents.

Our incidence estimate of $15 \%$ of the net present value of wind turbine profits 
or $7.5 \%$ of the net present value of the wind turbine subsidies translates - based on 2010 values - into capitalized wind turbine subsidies of 4,400 euros per hectare of land. This amounts to an increase of $27 \%$ of the land price per hectare. Since only counties with high wind strength benefit from the subsidies, we calculate the impact of land prices for counties with a wind strength above the median. For these counties, the capitalized wind turbine subsidies amount to 6,800 euros per hectare or to $44 \%$ of the average land price per hectare.

The estimated coefficients for the control variables except for the year dummies, the state trends and the county-fixed effects are shown in Table A.3 and A.4 in Appendix A. Most of the control variables are insignificant. Exceptions are the harvest corn variables, interacted with the West Germany dummy and the reform dummy, which we include to control for a recent finding by Breustedt and Habermann (2011). Their result show that the introduction of subsidies for biogas plants with the REA lead to an increase in farmland rental rates in proportion to the share of land used for corn in West Germany but not in East Germany. Our results are in line with their results but are only marginally significant. More precisely estimated is the stream of income due to biogas plants per hectare in euro, which we included as well to control for the biogas subsidies paid ${ }^{26}$ The correlation is 0.2 between the subsidies received per hectare and the average land price per hectare. Urban proximity measured by the inverse distance weighted population in neighbouring counties and the population density increases land prices as suggested by prior literature (Livanis et al. (2006); Guiling et al. (2009)). Finally, the coefficients for the three tax variables are negative, but only statistically significant for the local business tax.

Sensitivity Analysis: We start assessing the sensitivity of our results by altering the way we calculate the net present value of wind turbine profits. First, we use instead of the regional share of suitable land to build wind turbines, the German average share, which is $14 \%$ (Table A.5 in Appendix A, column (1)). The point estimate increase slightly to $15.8 \%$. In column (2) we use the net present value of wind turbine profits per hectare based on the profits of built wind turbines. The estimated coefficient increases to $20 \%$. This increase is not surprising since our main measure is likely to overestimate the true net present value of wind turbine profits

\footnotetext{
${ }^{26}$ The variable is derived by dividing the overall amount of subsidies for electricity generated by biogas plants by the installed capacity of biogas plants. Both variables stem from publications of the electricity network operators. We map the installed capacity of biogas plants to the county level to calculate the amount of subsidies for each county. Finally, the amount is scaled by the size of agricultural land.
} 
(as it is based on the newest available technology) while the second measure is likely to be the lower bound (as it is based on the used technology in the past). Thus, we conclude that the incidence share is between 15 and 20\%. The next robustness check concerns the Electricity Feed-in Act, which was in place up to 2000. In the baseline specification, we assumed investors to expect to receive the subsidy for up to 3 years, column (3) reports the results based on 5 years. The estimated coefficient increases but is still not significantly different from the baseline specification.

Further, we assess the sensitivity of our results with respect to differences between East and West Germany by including a different time trends for the two parts of Germany (Table A.6 in Appendix A, column (1)). This is motivated as a large share of agricultural land in East Germany before 2000 was held by the Bodenverwertung- und Verwaltung GmbH (BVVG) as in former East Germany agricultural land was collectively owned. The BBVG was founded to take over collectively owned land and to sell it with profit in the years after the reunification. Including a different time trend for West and East Germany has virtually no impact on the estimated coefficient. Moreover, we exclude counties with fewer than 100 transactions per year to assess whether small counties drive the results (Table A.6 in Appendix A, column (2)). Further, one might argue that prices based on fewer than 100 transactions are not representative. Again, the result is basically unchanged. Finally, we account for spatial dependence in transaction prices. Although our dependent variable is a county average transaction price and thus spatial dependence is likely to be of minor importance, it could still bias the results. In column (3) and (4) we include the inverse distance weighted transaction price of the neighbouring counties. Since the transaction price in neighboring counties is likely to be endogenous, we instrument the neighboring price in column (4) using the inverse distance weighted wind strength in combination with the introduction of the REA as instrument. The estimated coefficient decrease to $11 \%$, but it is still significantly estimated and not different from the baseline specification. Thus, overall we conclude that our results are robust across the different specifications.

\section{Impact of the Subsidies on Agricultural Land Owners' Income}

In order to provide a deeper understanding of the result, in this section we use the estimated incidence share to study the impact of wind turbine subsidies on 
agricultural land owners' income. To this end it is important to distinguish between turbines that are build on leased land and turbines that are build on (investors') own land, since in the first case land owners receive a yearly payment for 20 years whereas in the latter case land owners receive one non-recurring payment. Further, lease payments only increase if a turbine is built on the land, capital gains in contrast capture profits of wind turbines that may be built in the future as well 27

In more detail, in order to assess the overall impact on agricultural income, we calculate the increase in lease payments and the additional capital gains resulting from wind turbine subsidies. The calculation is based on the following information: (i) the estimated incidence share of $15 \%$ (ii) the net present value of profits of wind turbines built (for the lease payments) and the net present value of profits of potential wind turbines (for the capital gains), (iii) the fraction of wind turbines built on leased land and (iv) the amount of sold land suitable to build wind turbines.

Since the proportion of wind turbines built on leased land (iii) and the amount of sold land suitable to build wind turbines (iv) are not observed, we approximate them in the following way: For the proportion of wind turbines built on leased land we use the share of land that is newly leased per year to the overall amount of land that is newly leased or sold per year. The underlying idea is that investors interested in a particular field cannot choose whether to buy or to lease the particular field of land as this is determined by the land owner. The share of newly leased to overall newly leased and sold land is around $82 \%$ in 2010 German Federal Statistical Office $(2011 \mathrm{a}$ b) $)$. The amount of sold land suitable for building wind turbines is derived by multiplying the amount of land sold in a particular county and year (which is observed in the data) with the share of suitable land in that county (obtained from the German Enviromental Agency (2013)).

Lease payments: As a first step we calculate the lease payment for each wind turbine built in Germany. We assume that this is the yearly amount paid for 20 years, which is equivalent to $15 \%$ (our incidence share) of the net present value of profits of the plant ${ }^{28}$ The single lease payments are then aggregated for all plants within a county in a particular year. Since not all wind turbines have been built on leased land, we scaled the overall amount of lease payments in each county and year

\footnotetext{
${ }^{27}$ This is in line with one of the explanations proposed by Grainger (2012) why housing values react more strongly than rents to (current) improvements in air quality. If current improvements increase the likelihood of future improvements in air quality, house prices should respond stronger than rents as future improvements are only priced by sellers and buyers. Renters pay only for current air quality.

${ }^{28}$ The calculation is based on the following standard annuity formula and a discount rate of $3 \%$ : lease $_{i}=N P V W T_{i} *\left(1.03^{20} * 0.03\right) /\left(1.03^{20}-1\right)$.
} 
with the share of wind turbines built on leased land, which is $82 \%$.

Capital gains of land owners: Capital gains are calculated by multiplying the expected increase in the price per hectare due to the subsidy with the amount of sold land in a county suitable to build wind turbines. The expected increase in the price per hectare stems from our empirical results (see Table 4) and equals to $15 \%$ of the net present value of expected wind turbine profits per hectare.

In our estimation sample, the average amount of wind turbine subsidies received by all owners of land within one county is 1.6 million euros (see Table 5). For the year 2010 (2007), the overall amount is slightly higher with 2.2 (1.9) million euros. On average $1 / 3$ of the additional income is due to lease payments and $2 / 3$ due to capital gains. These shares do not vary much over time. To put these numbers into perspective, we relate them to the overall income that arises from agricultural land. Since agricultural land income is not separately reported for incorporated firms, we focus on West Germany for the comparison as in this part of Germany $99 \%$ of all agricultural land is owned by individuals or partnerships (German Federal Statistical Office (2011b)) ${ }^{29}$ For these land owners, we observe agricultural income in the income tax data. For the comparison we use the latest year available, which is 2007.30 As in our main analysis, we aggregate the agricultural income on the county level. Based on the income tax statistic, the additional income due to wind turbines that results from our calculation described above amounts to $4.3 \%$ of the average agricultural income in 2007 (see Table 5). When considering only counties with a wind strength above the median (above the 75 percentile), the share increases to $6.6 \%(8.2 \%)$. Wind turbine subsidies thus have a measurable impact on agricultural land owners' income.

Besides shedding light on the relative importance of wind turbine subsidies for agricultural land owners' income, we further exploit the income tax data to validate our analysis. In particular, if our estimation is correct, agricultural income should over time exactly increase by the estimated additional income - holding all our factors constant. We test this using a simple regression analysis framework. Since the income tax is also available for 1998, 2001 and 2004, we construct a countyyear level panel that covers all West German counties that are included in the main analysis ${ }^{31}$ The dependent variable is the overall agricultural income in a particular

\footnotetext{
${ }^{29}$ The fraction in East Germany is only $50 \%$. Further, a huge share of land in East Germany is owned by the BVVG.

${ }^{30}$ The data is a stratified sample of the almost 40 million taxpayers in Germany.

${ }^{31}$ Results are unchanged when including all West German, non-urban counties, independent whether they are included in the main estimation sample or not.
} 
Table 5: Quantification Impact on Agricultural Land Owners' Income

\begin{tabular}{|c|c|c|c|c|c|c|}
\hline \multirow[t]{4}{*}{ Sample } & \multirow[t]{4}{*}{$\mathrm{N}$} & Million & Agric. & \multicolumn{3}{|c|}{ Wind turbine income } \\
\hline & & hectare & Income & Lease & Capital & Overall \\
\hline & & of & & payments & gains & \\
\hline & & land & & in million euro & & in $\%$ \\
\hline Sample period 1997-2012 & 4,107 & & & 0.4 & 1.2 & \\
\hline Sample period 2010 & 274 & 14.5 & & 0.7 & 1.5 & \\
\hline Sample period 2007 & 272 & 14.6 & & 0.6 & 1.3 & \\
\hline West Germany 2007 & 221 & 10.4 & 34.7 & 0.6 & 0.9 & 4.3 \\
\hline West Germany 2007, WS > P50 & 106 & 5.6 & 38.1 & 1 & 1.5 & 6.6 \\
\hline West Germany 2007, WS > P75 & 56 & 3.6 & 47.4 & 1.6 & 2.3 & 8.2 \\
\hline
\end{tabular}

Notes: WS stands for wind strength, P50 for the median and P75 for the 75 th percentile.

Source: Author's calculation based on data of the German Weather Service, income tax statistic 1998, 2001, 2004, 2007, operator database 1990-2012, Statistik Lokal and Regional 1998-2012.

county and year. The main explanatory variable is our calculated additional income due to wind turbine subsidies. We further control for the return of agricultural land, the demand for agricultural products, the tax burden on land and state specific linear and quadratic time trends as in our main specification 32 Descriptive statistics for the sample are shown in Table A.7 in Appendix A.

The regression results are shown in Table 6. Column (1) shows the results without including any control variables, column (2) with the inclusion of the control variables. In column (2) the point estimates is 1.096, significant at the $5 \%$ level and clearly not statistically different from one. In column (3) we use the simulated increase in taxable income based on an incidence share of $20 \%$, which gives us an estimated coefficient of 0.822 , again significant at the $5 \%$ level and not different from one.

\section{Conclusions}

In this paper, we estimate the incidence of wind turbine subsidies into land prices exploiting regional variation in wind strength across counties in combination with the introduction of the REA for identification. Our results suggest that on average land owners reap between 7.5 and $10 \%$ of the expected potential net present value

\footnotetext{
${ }^{32}$ The variables capturing the agricultural return of land are not measured as share but as the actual amount of land. Further, to avoid biased results due to reversed causality, we use the 1998 land usage and interact the variables with year dummies. Due to the interaction with the year dummies, we control again for a potential different impact of land usage after the introduction of the REA as well a average changes in land usage. Due to multicollinearity problems we do not include the amount of grassland but only the amount of farmland.
} 
Table 6: Results Taxable Agricultural Income

\begin{tabular}{lccc}
\hline Dep. Var. & \multicolumn{2}{c}{ Agric. income in thd. euro } \\
\hline & $(1)$ & $(2)$ & $(3)$ \\
\hline Add. income due WT subsidies, incidence share of $15 \%$ & $1.615^{* * *}$ & $1.096^{* *}$ & \\
& $(0.444)$ & $(0.456)$ & \\
Add. income due WT subsidies, incidence share of 20\% & & & $0.822^{* *}$ \\
& & & $(0.342)$ \\
\hline$R^{2}$ & 0.243 & 0.474 & 0.474 \\
Observations & 890 & 890 & 890 \\
Control Variables & & & \\
Agric. Return & & $\mathrm{x}$ & $\mathrm{x}$ \\
Demand for Agric. Products & & $\mathrm{x}$ & $\mathrm{x}$ \\
Tax variables & & $\mathrm{x}$ & $\mathrm{x}$ \\
State specific time trend & & $\mathrm{x}$ & $\mathrm{x}$ \\
\hline
\end{tabular}

Notes: Table shows estimated coefficients for the impact of calculated income due to wind turbine subsidies on agricultural income on a county level. Sample includes all counties in West Germany in 1998, 2001,2004 and 2007, which are included in our main estimation sample. Each regression includes a full set of county and time dummies (not reported.) Robust standard errors, clustered at the county level, in parentheses. Significance levels: $* \mathrm{p}<0.1,{ }^{* *} \mathrm{p}<0.05,{ }^{* * *} \mathrm{p}<0.01$.

Source: Author's calculation based on data of the German Weather Service, income tax statistic 1998, 2001, 2004, 2007, operator database 1990-2007, Statistik Lokal and Regional 1998-2007.

of the subsidy or between 15 and $20 \%$ of the expected potential net present value of wind turbine profits. Based on these results, we calculate that in counties with a wind strength above the 75th percentile, wind turbine subsidies account for more than $8 \%$ of agricultural income in 2007.

The implications of our study are at least twofold. First, renewable energies subsidies based on a feed-in tariff are likely to generate windfalls profits for land owners, although the magnitude depends on the cost curve of investors. To minimize the resulting impact of RES subsidies on the income distribution, which is increasing in the share of sold land every year, land taxes may be used to finance the subsidies.

Second, land prices react to expectations and thus to the expected subsidy paid. The increase in land prices is thus much larger than the net present value of the subsidy of turbines built. Although redistribution can be achieved by taxing land rents accordingly, the increase in land prices may impact welfare directly if the most productive land buyers face financing constraints (e.g. Hart and Zingales (2013); Moore (2015)). This may be less severe in countries with highly developed financial markets and/or competitive banking sectors. It is however likely to be an important issue if this is not the case and financing constraints are a barrier to market entry (e.g. Rajan and Zingales (1998); Cetorelli and Strahan (2006)). 


\section{Acknowledgements}

We thank Gunnar Breustedt, Mike Devereux, Dominika Langenmayr, Beat Hintermann, Joel Slemrod as well as seminar participants at the DIW Berlin and Oxford University and participants at the IIPF conference 2015 in Dublin and the EEA conference 2015 in Mannheim for helpful comments. 


\section{References}

Alberici, S., Boeve, S., van Breevoort, P., Deng, Y., Förster, S., Ann Gardiner, V. v. G., Grave, K., Groenenberg, H., de Jager, D., Klaassen, E., Pouwels, W., Smith, M., de Visser, E., Winkel, T., Wouters, K., 2014. Subsidies and costs of eu energy - final report prepared for the european commission. https://ec.europa.eu/energy/sites/ener/files/documents/ECOFYS\%202014 \%20Subsidies\%20and\%20costs\%20of\%20EU\%20energy_11_Nov.pdf, last accessed: $17 / 12 / 2015$.

Besley, T., Rosen, H., 1999. Sales taxes and prices: An empirical analysis. National Tax Journal 52, 157-78.

Boccard, N., 2009. Capacity factor of wind power realized values vs. estimates. energy policy 37, 2679-2688.

Breustedt, G., Habermann, H., 2011. The incidence of eu per-hectare payments on farmland rental rates: A spatial econometric analysis of german farm-level data. Journal of Agricultural Economics 62, 225-243.

Carbonnier, C., 2007. Who pays sales taxes? Evidence from French VAT reforms, 1987-1999. Journal of Public Economics 91, 1219-1229.

Cetorelli, N., Strahan, P. E., 2006. Finance as a barrier to entry: Bank competition and industry structure in local u.s. markets. The Journal of Finance 61, 437-461.

Ciaian, P., Kancs, d., 2012. The capitalization of area payments into farmland rents: Micro evidence from the new eu member states. Canadian Journal of Agricultural Economics/Revue canadienne d'agroeconomie 60, 517-540.

Eichner, T., Runkel, M., 2014. Subsidizing renewable energy under capital mobility. Journal of Public Economics 117, 50-59.

Fullerton, D., 2009. Distributional Effects of Enviromental and Energy Policy: An Introduction. Distributional Effects of Enviromental and Energy Policy.

Gasch, R., Twele, J., eds. 2011. Windkraftanlagen: Grundlagen, Entwurf, Planung und Betrieb. Vieweg+Teubner Verlag, 7th edition.

German Enviromental Agency, 2013. Potenzial der Windenergie an Land - Studie zur Ermittlung des bundesweiten Flaechenund Leistungspotenzials der Windenergienutzung an Land. 
https://www.umweltbundesamt.de/sites/default/files/medien/378/publikationen /potenzial_der_windenergie.pdf, last accessed: 17/12/2015.

German Federal Statistical Office, 2011a. Eigentum und Pachtverhaeltnisse Landwirtschaftszaehlung 2010. Fachserie 3 Heft 3 German Federal Statistical Office, Wiesbaden.

German Federal Statistical Office, 2011b. Kaufwerte fuer landwirtschaftliche Grundstuecke 2010. Fachserie 3 Reihe 2.4. German Federal Statistical Office, Wiesbaden.

Grainger, C. A., Kolstad, C. D., 2010. Who pays a price on carbon? Enivormental and Resource Economics 46, 359-376.

Grainger, C. A., 2012. The distributional effects of pollution regulations: Do renters fully pay for cleaner air? Journal of Public Economics 96, 840 - 852.

Groesche, P., Schroeder, C., 2014. On the restributive effects of germany's feed-in tariff. Empirical Economics 46, 1339-1383.

Guiling, P., Brorsen, B. W., Doye, D., 2009. Effect of urban proximity on agricultural land values. Land Economics 85, 252-264.

Haas, R., Resch, G., Panzer, C., Busch, S., Ragwitz, M., Held, A., 2011. Efficiency and effectiveness of promotion systems for electricity generation from renewable energy sources - lessons from eu countries. Energy 36, 2186-2193.

Hart, O. D., Zingales, L., 2013. Liquidity and inefficient investment. NBER Working Paper 19184.

Hassett, K. A., Mathur, A., Metcalf, G. E., 2009. The incidence of a us carbon tax: A lifetime and regional analysis. The Energy Journal 30, 155-178.

Hendricks, N. P., Janzen, J. P., Dhuyvetter, K. C., 2012. Subsidy Incidence and Inertia in Farmland Rental Markets: Estimates from a Dynamic Panel. Journal of Agricultural and Resource Economics 37.

International Energy Agency, 2014. World energy outlook 2014. Paris : IEA Publications.

Johnstone, N., Hascic, I., Popp, D., 2010. Renewable energy policies and technological innovation: Evidence based on patent counts. Environmental and Resource Economics 45, 133-155. 
Kirwan, B., 2009. The incidence of u.s. agricultural subsidies on farmland rental rates. Journal of Political Economy 117, 138-164.

Klessmann, C., Held, A., Rathmann, M., Ragwitz, M., 2011. Status and perspectives of renewable energy policy and deployment in the european union - what is needed to reach the 2020 targets? Energy Policy 39, 7637-7657.

Livanis, G., Moss, C. B., Breneman, V. E., Nehring, R. F., 2006. Urban sprawl and farmland prices. American Journal of Agricultural Economics 88, 915-929.

Menanteau, P., Finon, D., Lamy, M.-L., 2003. Prices versus quantities: choosing policies for promoting the development of renewable energy. Energy Policy 31, 799-812.

Metcalf, G. E., 1999. A distributional analysis of green tax reforms. National Tax Journal 52.

Moore, J., 2015. Pecuniary externality through credit constraints: Two examples without uncertainty. http://www.ed.ac.uk/polopoly_fs/1.69237fileManager/PecuniaryExternality.pdf, last accessed: 17/12/2015.

Neuhoff, K., Bach, S., Diekmann, J., Besznoska, M., El-Laboudy, T., 2012. Steigende EEG-Umlage: Unerwuenschte Verteilungseffekte koennen vermindert werden. DIW Weekly Report 41/2012.

Parry, I. W., 2004. Are emissions permits regrssive? Journal of Environmental Economics and Management 47, 364-387.

Poterba, J. M., 1996. Retail price reactions to changes in state and local sales taxes. National Tax Journal, 165-176.

Rajan, R. G., Zingales, L., 1998. Financial Dependence and Growth. American Economic Review 88, 559-86.

Requate, T., 2014. Green tradable certificates versus feed-in tariffs in the promotion of renewable energy shares. CESifo Working Paper 5149.

Roberts, M., Kirwan, B., Hopkins, J., 2003. The incidence of government program payments on agricultural land rents: The challenges of identification. American Journal of Agricultural Economics 85, 762-769. 
Sallee, J. M., 2011. The surprising incidence of tax credits for the toyota prius. American Economic Journal: Economic Policy, 189-219.

Suárez Serrato, J., Zidar, O., 2014. Who benefits from state corporate tax cuts? a local labor market approach with heterogenous firms.. NBER Working Paper 20289.

Titman, S., 1985. Urban land prices under uncertainty. The American Economic Review 75, pp. 505-514. 


\section{A Appendix - Additional Descriptive Statistics, Figures and Regression Results}

Table A.1: Composition of the Sample and Representativity

\begin{tabular}{c|cc|cc}
\hline & \multicolumn{3}{|c}{ Germany } & \multicolumn{2}{c}{ Sample } \\
\hline Year & $\begin{array}{c}\text { Produced wind } \\
\text { electricity (WTE) in GWh }\end{array}$ & $\begin{array}{c}\text { No of } \\
\text { plants }\end{array}$ & $\begin{array}{c}\text { Produced WTE } \\
\text { in \% of total }\end{array}$ & $\begin{array}{c}\text { No of plants } \\
\text { in \% of total }\end{array}$ \\
\hline 1997 & 2,490 & 4,387 & 48.3 & 49.9 \\
1998 & 3,480 & 5,346 & 90.9 & 88.8 \\
1999 & 5,229 & 6,954 & 89.0 & 86.9 \\
2000 & 7,687 & 8,447 & 86.7 & 85.5 \\
2001 & 11,093 & 10,482 & 86.0 & 84.3 \\
2002 & 15,639 & 12,743 & 85.8 & 84 \\
2003 & 20,255 & 14,458 & 84.9 & 83.8 \\
2004 & 24,118 & 15,642 & 84.3 & 82.9 \\
2005 & 27,187 & 16,705 & 87.2 & 86.1 \\
2006 & 30,359 & 17,902 & 86.5 & 84.8 \\
2007 & 33,572 & 18,774 & 85.8 & 85.2 \\
2008 & 36,317 & 19,581 & 86.2 & 84.8 \\
2009 & 39,175 & 20,503 & 85.7 & 85.3 \\
2010 & 41,996 & 21,212 & 86.1 & 79.2 \\
2011 & 45,083 & 22,077 & 80.1 & 79.1 \\
2012 & 49,000 & 23,001 & 80.3 & \\
\hline
\end{tabular}

Source: Author's calculation based on operator database 1990-2012. 
Figure A.1: Technological Development Wind Turbines

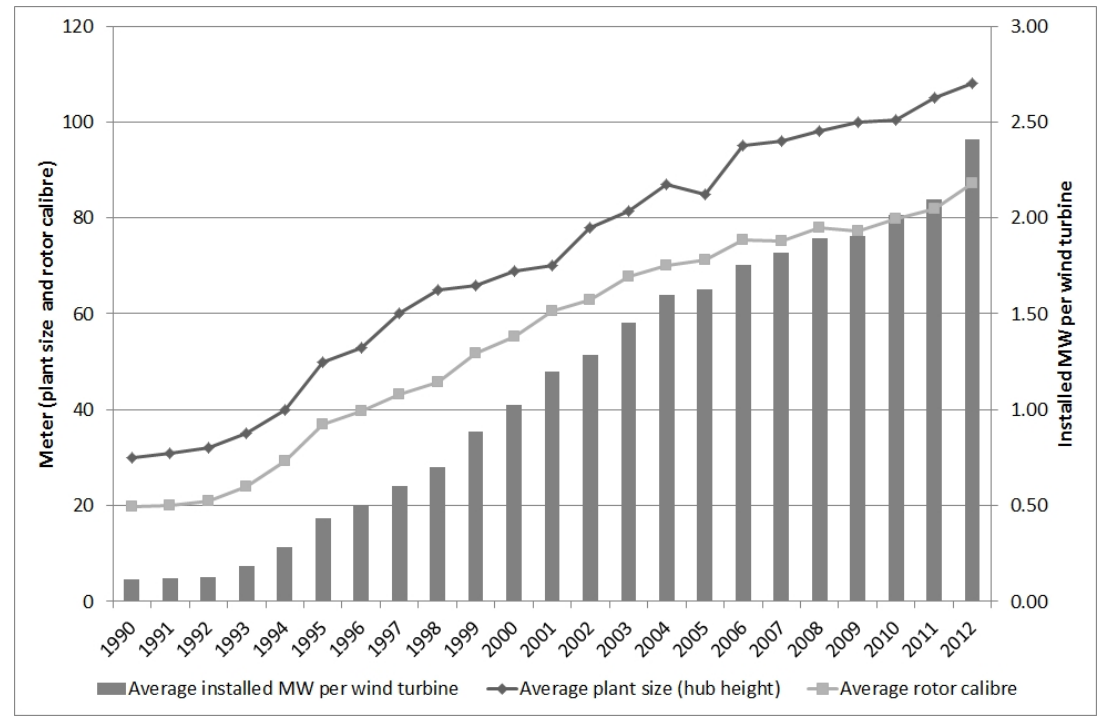

Notes: Averages are based on all wind turbines built in Germany in a current year. Source: Author's calculations based on operator database 1990-2012.

Table A.2: First Stage Results

\begin{tabular}{lcccc}
\hline Dep. Var. & \multicolumn{4}{c}{ NPV WT profits ph } \\
\hline \multicolumn{1}{l}{$(1)$} & $(2)$ & $(3)$ & $(4)$ \\
\hline $\mathrm{D}(\mathrm{WS}>\mathrm{P} 50)^{*} \mathrm{D}(>1999)$ & $\begin{array}{c}9556.319^{* * *} \\
(642.514)\end{array}$ & $\begin{array}{c}6053.032^{* * *} \\
(544.638)\end{array}$ & & \\
& & & $11478.816^{* * *}$ & $10042.394^{* * *}$ \\
& & & $(701.880)$ & $(801.565)$ \\
\hline$R^{2}$ & 0.678 & 0.787 & 0.700 & 0.795 \\
Observations & 4,107 & 4,107 & 4,107 & 4,107 \\
Control Variables & & & & $\mathrm{x}$ \\
$\quad$ Agric. return & & $\mathrm{x}$ & & $\mathrm{x}$ \\
Demand for agric. products & & $\mathrm{x}$ & $\mathrm{x}$ \\
Tax variables & & $\mathrm{x}$ & $\mathrm{x}$ \\
State specific time trend & & $\mathrm{x}$ & & \\
\hline
\end{tabular}

Notes: Table shows estimated coefficients for the first stage regression. WS stands for wind strength, and NPV WT profits ph for net present value of expected wind turbine profits per hectare. Robust standard errors, clustered at the county level, in parentheses. Significance levels: ${ }^{*} \mathrm{p}<0.1,{ }^{* *} \mathrm{p}<0.05,{ }^{* * *} \mathrm{p}<0.01$.

Source: Author's calculation based on data of the German Weather Service, operator database 1990-2012, Statistik Lokal and Regional 1997-2012, Statistical Offices of the Laender 1997-2012. 
Table A.3: Estimated Coefficients for the Control Variables in Table 4: Part I

\begin{tabular}{|c|c|c|c|}
\hline \multirow{2}{*}{$\frac{\text { Dep. Var. }}{\text { Column in Table } 4}$} & \multicolumn{3}{|c|}{ Land price in euro ph } \\
\hline & $(2)$ & (4) & (6) \\
\hline \multirow[t]{2}{*}{ Share grassland } & -333.572 & -347.897 & -347.262 \\
\hline & $(342.881)$ & $(318.655)$ & $(318.856)$ \\
\hline \multirow[t]{2}{*}{ Share grassland*Introduction REA (1) } & -14.900 & -25.046 & -24.597 \\
\hline & $(25.550)$ & $(25.603)$ & $(25.762)$ \\
\hline \multirow[t]{2}{*}{ Share farmland } & -196.212 & -197.501 & -197.444 \\
\hline & $(345.805)$ & $(326.336)$ & $(326.567)$ \\
\hline \multirow[t]{2}{*}{ Share farmland*(1) } & $-75.043^{*}$ & -70.225 & $-70.439^{*}$ \\
\hline & $(44.525)$ & $(42.893)$ & $(42.811)$ \\
\hline \multirow[t]{2}{*}{ Share land cereal } & 83.820 & 52.644 & 54.026 \\
\hline & $(159.567)$ & $(159.332)$ & $(160.845)$ \\
\hline \multirow[t]{2}{*}{ Share land cereal $^{*}(1)$} & 157.300 & 153.576 & 153.741 \\
\hline & $(133.690)$ & $(130.390)$ & $(130.151)$ \\
\hline \multirow[t]{2}{*}{ Share land root crop } & -91.788 & -310.302 & -300.618 \\
\hline & $(294.563)$ & $(332.693)$ & $(316.345)$ \\
\hline \multirow[t]{2}{*}{ Share land root crop $*(1)$} & 35.495 & 101.001 & 98.098 \\
\hline & $(209.577)$ & $(216.176)$ & $(211.202)$ \\
\hline \multirow[t]{2}{*}{ Share land forage crop } & -66.538 & 62.443 & 56.727 \\
\hline & $(223.668)$ & $(232.777)$ & $(231.243)$ \\
\hline \multirow[t]{2}{*}{ Share land forage crop*(1) } & 168.359 & -22.342 & -13.890 \\
\hline & $(176.808)$ & $(200.794)$ & $(191.955)$ \\
\hline \multirow[t]{2}{*}{ Harvest ph wheat } & 19.890 & 43.523 & 42.476 \\
\hline & $(66.973)$ & $(69.019)$ & $(66.298)$ \\
\hline \multirow[t]{2}{*}{ Harvest ph wheat*(1) } & 22.590 & 2.924 & 3.796 \\
\hline & $(51.203)$ & $(50.609)$ & $(48.869)$ \\
\hline \multirow[t]{2}{*}{ Harvest ph potatoes } & 3.738 & 2.678 & 2.725 \\
\hline & $(3.159)$ & $(3.231)$ & $(3.178)$ \\
\hline \multirow[t]{2}{*}{ Harvest ph potatoes $*(1)$} & -2.746 & -2.006 & -2.038 \\
\hline & $(2.267)$ & $(2.257)$ & $(2.241)$ \\
\hline \multirow[t]{2}{*}{ Harvest ph corn } & -4.625 & -2.149 & -2.259 \\
\hline & $(5.801)$ & $(5.745)$ & $(5.689)$ \\
\hline \multirow[t]{2}{*}{ Harvest ph corn *West Germany (WG) } & 5.465 & 3.551 & 3.636 \\
\hline & $(5.044)$ & $(4.989)$ & $(4.943)$ \\
\hline \multirow[t]{2}{*}{ Harvest ph corn*(1) } & -0.889 & -7.304 & -7.019 \\
\hline & $(4.791)$ & $(5.452)$ & $(5.038)$ \\
\hline \multirow[t]{2}{*}{ Harvest ph corn*WG*(1) } & 0.175 & 4.927 & $4.717^{*}$ \\
\hline & $(2.274)$ & $(3.189)$ & $(2.727)$ \\
\hline$R^{2}$ & 0.330 & 0.308 & 0.310 \\
\hline Observations & 4,107 & 4,107 & 4,107 \\
\hline \multicolumn{4}{|l|}{ Control Variables } \\
\hline State specific time trend & $\mathrm{x}$ & $\mathrm{x}$ & $\mathrm{x}$ \\
\hline
\end{tabular}

Notes: Table shows estimated coefficients for the control variables in column (2), (4) and (6) in Table 4. Each regression includes a full set of county and time dummies (not reported.) $\mathrm{pH}$ stands for per hectare. Robust standard errors, clustered at the county level, in parentheses. Significance levels: ${ }^{*} \mathrm{p}<0.1,{ }^{* *} \mathrm{p}<0.05,{ }^{* * *} \mathrm{p}<0.01$.

Source: Author's calculation based on data of the German Weather Service, Operator Database 1990-2012, Statistik Lokal and Regional 1998-2012, Statistical Offices of the Laender 1997-2012. 
Table A.4: Estimated Coefficients for the Control Variables in Table 4: Part II

\begin{tabular}{|c|c|c|c|}
\hline \multirow{2}{*}{$\frac{\text { Dep. Var. }}{\text { Column in Table } 4}$} & \multicolumn{3}{|c|}{ Land price in euro ph } \\
\hline & $(2)$ & $(4)$ & $(6)$ \\
\hline \multirow[t]{2}{*}{ Harvest ph wheat*Share land cereal } & -1.431 & -1.270 & -1.277 \\
\hline & $(1.719)$ & $(1.729)$ & $(1.741)$ \\
\hline \multirow[t]{2}{*}{ Harvest ph wheat*Share land cereal $^{*}(1)$} & -0.403 & -0.445 & -0.443 \\
\hline & $(1.425)$ & $(1.391)$ & $(1.394)$ \\
\hline \multirow[t]{2}{*}{ Harvest ph potatoes*Share land root crop } & 0.411 & 0.607 & 0.599 \\
\hline & $(0.502)$ & $(0.528)$ & $(0.511)$ \\
\hline \multirow[t]{2}{*}{ Harvest ph potatoes*Share land root crop*(1) } & 0.105 & -0.067 & -0.059 \\
\hline & $(0.459)$ & $(0.478)$ & $(0.464)$ \\
\hline \multirow[t]{2}{*}{ Harvest ph $\operatorname{corn}^{*}$ Share land forage crop } & 0.517 & 0.046 & 0.067 \\
\hline & $(0.605)$ & $(0.673)$ & $(0.654)$ \\
\hline \multirow[t]{2}{*}{ Harvest ph corn*Share land forage crop*WG } & $-0.956^{* *}$ & $-0.808^{*}$ & $-0.815^{*}$ \\
\hline & $(0.434)$ & $(0.461)$ & $(0.454)$ \\
\hline \multirow[t]{2}{*}{ Harvest ph corn*Share land forage crop*(1) } & 0.007 & 0.824 & 0.788 \\
\hline & $(0.526)$ & $(0.688)$ & $(0.630)$ \\
\hline \multirow[t]{2}{*}{ Harvest ph corn*Share land forage crop* $\mathrm{WG}^{*}(1)$} & -0.126 & -0.549 & $-0.531^{*}$ \\
\hline & $(0.260)$ & $(0.355)$ & $(0.319)$ \\
\hline \multirow[t]{2}{*}{ Share land farms stock breeding } & 3883.510 & 2070.352 & 2150.704 \\
\hline & $(5927.294)$ & $(5839.854)$ & $(5972.813)$ \\
\hline \multirow[t]{2}{*}{ Share land farms stock breeding $*(1)$} & 866.073 & 253.262 & 280.420 \\
\hline & $(1606.760)$ & $(1638.475)$ & $(1616.814)$ \\
\hline \multirow[t]{2}{*}{ Biogas plant income ph in euro } & $0.199^{* *}$ & $0.197^{* *}$ & $0.197^{* *}$ \\
\hline & $(0.100)$ & $(0.098)$ & $(0.098)$ \\
\hline \multirow[t]{2}{*}{$\log ($ Population $)$} & 0.003 & 0.004 & 0.004 \\
\hline & $(0.003)$ & $(0.003)$ & $(0.003)$ \\
\hline \multirow[t]{2}{*}{$\log ($ Distance weighted population $)$} & $0.001^{* * *}$ & $0.001^{* * *}$ & $0.001^{* * *}$ \\
\hline & $(0.000)$ & $(0.000)$ & $(0.000)$ \\
\hline \multirow[t]{2}{*}{ Population density } & $2607.076^{* * *}$ & $2947.218^{* * *}$ & $2932.145^{* * *}$ \\
\hline & $(708.788)$ & $(702.648)$ & $(690.139)$ \\
\hline \multirow[t]{2}{*}{ Average wage income } & 0.063 & 0.223 & 0.216 \\
\hline & $(0.827)$ & $(0.840)$ & $(0.834)$ \\
\hline \multirow[t]{2}{*}{ Unemployment rate } & $9696.307^{* *}$ & $12693.452^{* * *}$ & $12560.630^{* * *}$ \\
\hline & $(4254.033)$ & $(4467.385)$ & $(4272.679)$ \\
\hline \multirow[t]{2}{*}{ Property tax on agricultural land } & -1.778 & -1.709 & -1.712 \\
\hline & $(2.381)$ & $(2.399)$ & $(2.392)$ \\
\hline \multirow[t]{2}{*}{ Property transfer tax } & -423.150 & -124.187 & -137.436 \\
\hline & $(269.230)$ & $(313.861)$ & $(298.347)$ \\
\hline \multirow[t]{2}{*}{ Local business tax } & $-5.048^{*}$ & $-7.217^{* *}$ & $-7.121^{* *}$ \\
\hline & $(3.051)$ & $(3.209)$ & $(3.129)$ \\
\hline$R^{2}$ & 0.330 & 0.308 & 0.310 \\
\hline Observations & 4,107 & 4,107 & 4,107 \\
\hline \multicolumn{4}{|l|}{ Control Variables } \\
\hline State specific time trend & $\mathrm{x}$ & $\mathrm{x}$ & $\mathrm{x}$ \\
\hline
\end{tabular}

Notes: Table shows estimated coefficients for the control variables in column (2), (4) and (6) in Table 4. Each regression includes a full set of county and time dummies (not reported). $\mathrm{pH}$ stands for per hectare. Robust standard errors, clustered at the county level, in parentheses. Significance levels: ${ }^{*} \mathrm{p}<0.1,{ }^{* *} \mathrm{p}<0.05,{ }^{* * *} \mathrm{p}<0.01$.

Source: Author's calculation based on data of the German Weather Service, operator Database 1990-2012, Statistik Lokal and Regional 1998-2012, Statistical Offices of the Laender2 $21997-2012$. 
Table A.5: Sensitivity Analysis: Modeling NPV WT Profits

\begin{tabular}{lccc}
\hline Dep. Var. & \multicolumn{3}{c}{ Land price in euro ph } \\
\hline Excluded instrument & \multicolumn{3}{c}{ WS * $\mathrm{D}(>1999)$} \\
& $\begin{array}{c}\text { Alternative NPV WT profits } \\
\text { av. land }\end{array}$ & current & EFA \\
& share & profits & 5 years \\
\hline & $(1)$ & $(2)$ & $(3)$ \\
\hline NPV WT profits ph & $0.158^{* * *}$ & $0.195^{* *}$ & $0.257^{* * *}$ \\
& $(0.054)$ & $(0.077)$ & $(0.091)$ \\
\hline$R^{2}$ & 0.306 & 0.162 & 0.266 \\
Observations & 4,107 & 4,107 & 4,107 \\
Control Variables & & & \\
Agric. return & $\mathrm{x}$ & $\mathrm{x}$ & $\mathrm{x}$ \\
Demand for agric. products & $\mathrm{x}$ & $\mathrm{x}$ & $\mathrm{x}$ \\
Tax variables & $\mathrm{x}$ & $\mathrm{x}$ & $\mathrm{x}$ \\
State specific time trend & $\mathrm{x}$ & $\mathrm{x}$ & $\mathrm{x}$ \\
Shea's partial $R^{2}$ & 0.079 & 0.014 & 0.032 \\
F-Statistic & 141 & 18 & 56 \\
\hline
\end{tabular}

Notes: Table shows estimated coefficients for sensitivity analysis with respect to modelling the net present value of wind turbine profits. WS stands for wind strength, and NPV WT profits $\mathrm{pH}$ for net present value of wind turbine profits per hectare. In column (1) we use the average share of suitable land instead of the regional share. In column (2) we use profits of wind turbines built instead of the profits of the average technology wind turbine. In column (3) we assumed that investors expected to receive the feed-in tariff under the Electricity Feed-in Act for 5 years instead of 3 years. Each regression includes a full set of county and time dummies (not reported). Robust standard errors, clustered at the county level, in parentheses. Significance levels: ${ }^{*} \mathrm{p}<0.1$, ** $\mathrm{p}<0.05,{ }^{* * *} \mathrm{p}<0.01$.

Source: Author's calculation based on data of the German Weather Service, operator database 1990-2012, Statistik Lokal and Regional 1997-2012, Statistical Offices of the Laender 1997-2012. 
Table A.6: Sensitivity Analysis: Sample and Control Variables

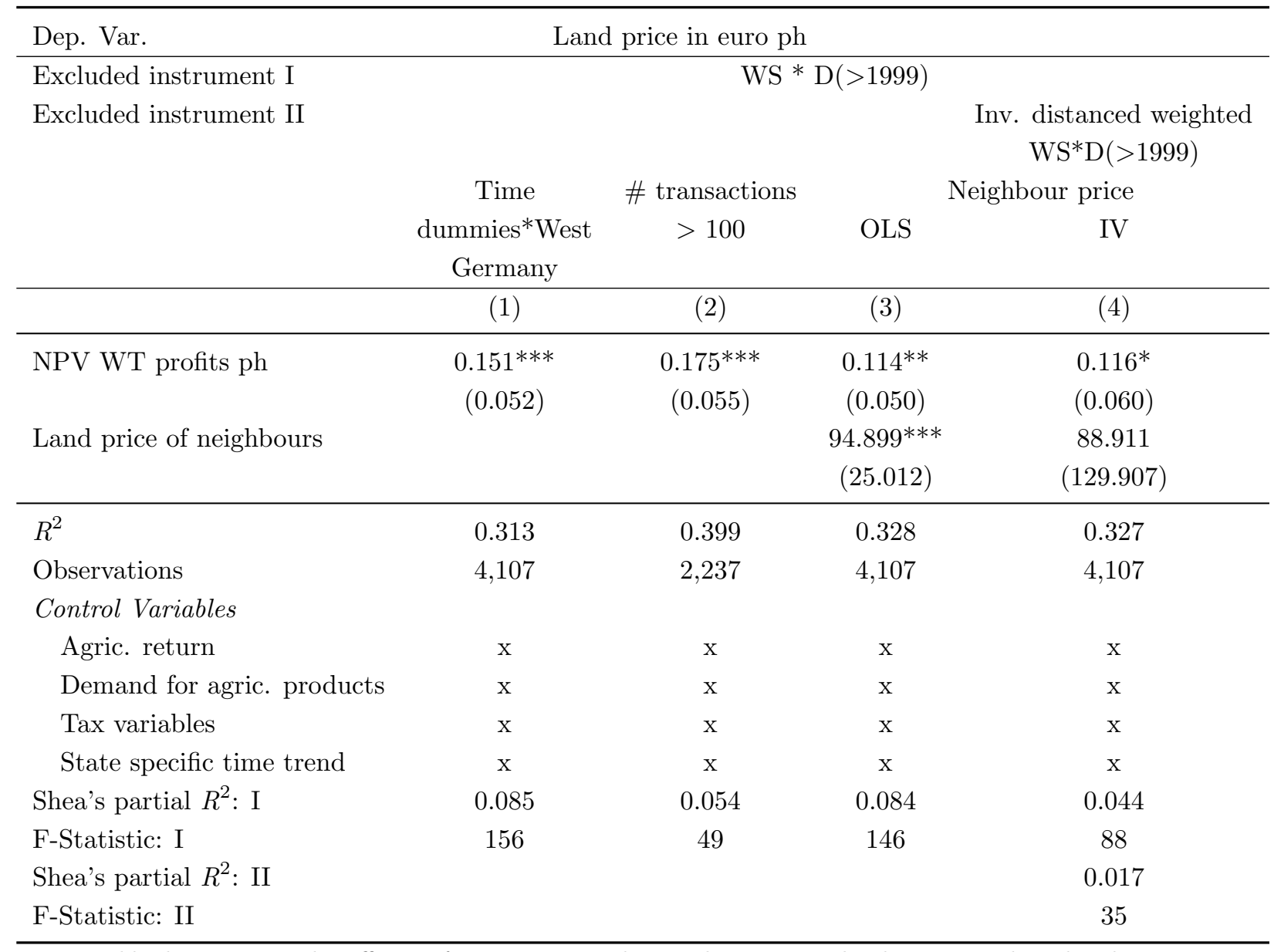

Notes: Table shows estimated coefficients for sensitivity analysis with respect to the choosen sample and with respect to including additional control variables. WS stands for wind strength, and NPV WT profits pH stands for net present value of expected wind turbine profits per hectare. Each regression includes a full set of county and time dummies (not reported). Robust standard errors, clustered at the county level, in parentheses. Significance levels: $* \mathrm{p}<0.1, * * \mathrm{p}<0.05, * * * \mathrm{p}<$ 0.01 .

Source: Author's calculation based on data of the German Weather Service, operator Database 1990-2012, Statistik Lokal and Regional 1997-2012, Statistical Offices of the Laender 1997-2012. 
Table A.7: Descriptive Statistics Taxable Agricultural Income

\begin{tabular}{|c|c|c|c|c|c|c|}
\hline Variable & $\mathrm{N}$ & Mean & $\mathrm{P} 25$ & $\mathrm{P} 50$ & P75 & SD \\
\hline Taxable agricultural income in thd. euros & 890 & 30,122 & 13,501 & 26,009 & 41,250 & 21,130 \\
\hline Lease payments due to wind turbines in thd. euros & 890 & 289 & 0 & 14 & 183 & 763 \\
\hline Capital gains due to wind turbines in thd. euros & 890 & 689 & 83 & 256 & 683 & 1,270 \\
\hline Increase in taxable income in thd. euros $(15 \%)$ & 890 & 978 & 91 & 306 & 968 & 1,928 \\
\hline Increase in taxable income in thd. euros $(20 \%)$ & 890 & 1,304 & 122 & 408 & 1,290 & 2,571 \\
\hline Number of single tax payers & 890 & 57,689 & 35,328 & 46,192 & 71,516 & 33,342 \\
\hline Number of couples & 890 & 4,629 & 2,000 & 3,593 & 6,001 & 4,658 \\
\hline \multicolumn{7}{|l|}{ Agricultural return } \\
\hline Farmland 1998 in thd. ha & 890 & 3012 & 1345 & 2,673 & 4,264 & 2,131 \\
\hline Land cereal 1998 in thd. ha & 890 & 1696 & 716 & 1,530 & 2,247 & 1,198 \\
\hline Land root crop 1998 in thd. ha & 890 & 251 & 23 & 85 & 288 & 402 \\
\hline Land forage crop 1998 in thd. ha & 890 & 506 & 139 & 313 & 659 & 563 \\
\hline Harvest ph wheat in tons & 890 & 7.4 & 6.6 & 7.4 & 8.2 & 1.1 \\
\hline Harvest ph potatoes in tons & 890 & 35.9 & 31.2 & 35.5 & 40.3 & 7.4 \\
\hline Harvest ph corn in tons & 890 & 45.8 & 43.5 & 46.1 & 48.8 & 5.2 \\
\hline Farms with cattle rearing 1998 in thd. ha & 890 & 37 & 18 & 31 & 51 & 26 \\
\hline Biogas plants income in thd. euros & 890 & 1,987 & 0 & 83 & 1,465 & 4,635 \\
\hline \multicolumn{7}{|l|}{ Demand for agricultural products } \\
\hline $\log$ (Population) & 890 & 12 & 11.7 & 12 & 12.4 & 0.5 \\
\hline $\log ($ Distance weighted population) & 890 & 14 & 12.2 & 14.2 & 15.6 & 2.5 \\
\hline Population density & 890 & 5.7 & 2.4 & 3.6 & 6.7 & 6 \\
\hline Average wage income per month in euro & 890 & 2,190 & 1,114 & 1,699 & 2,810 & 1,495 \\
\hline Unemployment rate & 890 & 0.07 & 0.05 & 0.07 & 0.08 & 0.05 \\
\hline \multicolumn{7}{|l|}{ Tax variables } \\
\hline Property tax on agricultural land & 890 & 295 & 266 & 300 & 326 & 50 \\
\hline Property transfer tax & 890 & 3.5 & 3.5 & 3.5 & 3.5 & 0 \\
\hline Local business tax & 890 & 339 & 319 & 332 & 349 & 29 \\
\hline
\end{tabular}

Notes: Property tax on agricultural land is the average multiplier in the county. To derive the tax rate the multiplier has to be multiplied with $6 \%$. Local business tax is the average local business tax multiplier in the county. To derive the tax rate the multiplier has to be multiplied with $0.05 \%$ before 2008 and $0.035 \%$ after 2007. ph stands for per hectare. Sample includes all counties in West Germany in 1998, 2001, 2004 and 2007 that are included in the main estimation analysis. Source: Author's calculation based on data of the German Weather Service, income tax statistic 1998, 2001, 2004, 2007, operator database 1990-2007, Statistik Lokal and Regional 1998-2007. 


\section{B Appendix - Theoretical Framework}

In this Appendix, we propose a theoretical model following Titman (1985) to formalize the assumption of the empirical analysis that the expected price of each field of land increases due to the introduction of the REA, independent whether a turbine has been built on a field during our sample period or not. We show this by comparing the price of vacant land in period 1 with the price an investor pays to a land owner in period 1 to build a wind turbine on that land.

Suppose, there are two type of agents, land owners and investors, which live three time periods. Each land owner owns one field at the beginning of period 1. All fields are of equal size and quality and differ only with respect to the wind strength on the field. The agricultural value of land is thus the same for each piece of land and is assumed to be zero ${ }^{33}$ Further, we assume that land owners do not build wind turbines on their own land and that wind turbines do not affect the agriculture return of land. In total there exist $K$ fields.

There a $N(>K)$ investors, each of them endowed with one unit of capital at the beginning of period 1 . The investors differ in their degree of risk aversion. They maximize their wealth and can choose whether to invest in a one year private capital market investment, yielding return $r$, or in wind turbines. The wind turbine investment is a two year investment and yields a net-of-costs return $\pi$ (due to the subsidy) at the end of the investment period. Investment costs are 1. As there are only three periods, wind turbines can only be built in the first two periods. The wind turbine investment is risky in period 1 as wind turbines are a new technology. In the second period, all problems related to the new technology are solved with probability $s_{H}$ making the wind turbine investment as certain as the private capital market investment. With probability $s_{L}=\left(1-s_{H}\right)$, problems still exists and the uncertainty remains. Due to difference in the degree of risk aversion, in period 1 only $N_{1}(<K)$ sufficiently risk loving investors enter the market. If all problems are solved in period 2, all remaining investors enter the market $\left(N_{2}\right)$ causing excess demand for land, or the number of investors stays the same.

If land owners and investors bargain with each other, land owners bargaining strength is given by $\beta$, which is mainly determined by the market conditions. In the case of excess supply of land, $\beta$ is zero as investors can easily find another suitable piece of land on which to build a wind turbine. In the case of excess demand, $\beta$ is

\footnotetext{
${ }^{33}$ This assumption is not crucial for the analysis, it only means that the price of land is solely determined by wind turbine profits. The assumption allows us to keep the analysis as simple as possible at the costs of land and capital having different returns.
} 
one due to the low substitution elasticity.

Based on these assumptions, we derive first the price of vacant land $k$, which is the expected price of land $k$ in period 2 (Titman (1985)). The price of land $k\left(A_{k, 2}\right)$ in period 2 can be derived using a bargaining framework. The outside option of land owners is the agricultural return of land in period 2 and 3 , which is set to zero by assumption. Investors' outside option is to invest in the private capital market in period 2 and 3, which has a discounted value of 1 . The outcome of the bargaining process for the $k$ field in period 2 is thus given by

$$
A_{k, 2}=\arg \max \Omega_{k, 2}
$$

with

$$
\begin{gathered}
\Omega_{k, 2}=\beta_{2} \ln \left(A_{k, 2}\right)+\left(1-\beta_{2}\right) \ln \left(\frac{\pi_{k, 2}}{(1+r)^{2}}-1\right) \\
A_{k, 2}=\beta_{2} \frac{\pi_{k, 2}-(1+r)^{2}}{(1+r)^{2}}
\end{gathered}
$$

Rearranging the first order condition (equation (B.2)) shows that the price of land equals a share $\beta_{2}$ of the discounted wind turbine profits, after deducting the value of investors outside option $\left((1+r)^{2}\right)$. From the point of view in period 1 , it is not clear whether all technical problems related to wind turbines will be solved in period 2 (with probability $s_{H}$ ) or not $\left(1-s_{H}\right.$ ). If they are solved, $\beta_{2}$ is one as there will be excess supply due to the additional investors entering the market. If they are not solved, $\beta_{2}$ will be zero.

The price of vacant land in period 1 can thus be written as the value of land in the two states of nature in period 2 , multiplied with the respective probabilities (see equation B.4). This is nothing other than the net present value of wind turbine profits after deducting investors' opportunity costs multiplied by the probability that there will be more investors than fields available in period $2 s_{H}$, see equation (B.5)). The whole expression is discounted by one period as it is the land price of tomorrow.

$$
\begin{gathered}
p_{k, 1}^{*}=\frac{s_{H} *\left[\frac{\pi_{k, 2}-1}{(1+r)^{2}}\right]+\left(1-s_{H}\right) * \frac{0}{(1+r)^{2}}}{(1+r)} \\
p_{k, 1}^{*}=s_{H} * \frac{\pi_{k, 2}-(1+r)^{2}}{(1+r)^{3}}
\end{gathered}
$$


In the next step, we show that this price is also paid by an investor to build a wind turbine in period 1 . We derive this price using the bargaining framework again. In contrast to period 2, land owners' outside option in period 1 is to reject the offer by the investor and to receive the expected share of profits reaped in the next period, discounted by one period. This outside option value has thus the same value as the price of vacant land. If the investor buys the land today, he earns $\pi$ in period 2 , discounted by two periods, and pays today $A_{k, 1}$. The investor's outside option is also to wait, invest in the capital market for one period, and to buy the land and to build a turbine in the next period and invest the remaining capital into the private capital market again. The value of this outside option is thus the discounted capital market investment return for one year $\left(\frac{r}{(1+r)}\right)$ and the expected net present value of profits of the wind turbine builds in period 2 on the same piece of land. From the point of view in period 1 , the investor will receive with probability $s_{H}$ in period 3 only the capital market return for a wind turbine investment in period 2, with probability $1-s_{H}$ he receives the whole surplus of the wind turbine.

The outcome of the bargaining process for the $k$ field in period 1 is given by

$$
A_{k, 1}=\arg \max \Omega_{k, 1}
$$

with

$$
\begin{aligned}
& \Omega_{k, 1}= \beta_{1} \ln \left(A_{k, 1}-s_{H}\left[\frac{\pi_{k, 2}-(1+r)^{2}}{(1+r)^{3}}\right)\right. \\
&+\left(1-\beta_{1}\right) \ln \left(\frac{\pi_{k, 1}}{(1+r)^{2}}-A_{k, 1}-\left[\frac{r}{(1+r)}+\left(1-s_{H}\right) \frac{\pi_{k, 2}}{(1+r)^{3}}+s_{H} \frac{(1+r)^{2}}{(1+r)^{3}}\right]\right) \\
& A_{k, 1}=s_{H} \frac{\pi_{k, 1}-(1+r)^{2}}{(1+r)^{3}}
\end{aligned}
$$

The rearranged first oder condition, using $\pi_{k, 1}=\pi_{k, 2}$ and $\beta_{1}=0$ due to excess supply of land, is given by equation (B.8). This is the same expression as derived for the price of vacant land in equation (B.5). Thus, the price of suitable land to build wind turbines increases independent whether a turbine is build or not. 


\section{Appendix - Microsimulation of the Net Present Value of Wind Turbine Profits}

In the following, we describe the simulation of wind turbine profits. We explain the microsimulation for the case of simulating the expected net present value of profits of wind turbine built, as this particular application is used to calibrate the model to fit aggregated values. The expected net present value of profits of wind turbines built is also used in the analysis of the impact of agricultural income due to wind turbine subsidies.

The main application of the model is to compute the expected net present value of profits of a county and year representative wind turbine which is used for the estimation of the incidence share. The main difference to the calculation of the expected net present value of profits of a particular wind turbine built is that we used year average technology characteristics for the representative wind turbine and that there is a representative wind turbine in each county and year, regardless whether a turbine has been built in that county and year or not.

The input used for the calculation of the net present value of built wind turbine profits are i) information on the average wind strength in 10 metre and 80 metre above ground, available in a 1 square kilometre raster for the whole of Germany, ii) the location and the technological details of each wind power plant in Germany and iii) the feed in tariff.

Since we only observe the county in which a turbine is located, we map the wind strength data to the county level. More precisely, we map the wind data to the German municipality level and then weight the wind strength on the municipality level with the share of agricultural land in the municipalities to the county level.

The energy produced by a wind turbine depends on the wind strength at the hub height and the technological details of the turbine. For a given roughness parameter $\left(z_{o}\right)$, which accounts for the impact of the shape of the landscape and a given wind strength in one height, the wind strength in every other height can be calculated (see equation (C.1)). Since the average wind strength in 10 metre and 80 metre above ground is given, the roughness parameter is calculated first and then the average wind strength at the hub height.

$$
w s_{i}=w s_{j} * \frac{\ln \left(\frac{\text { height }_{i}}{z_{0}}\right)}{\ln \left(\frac{\text { height }_{j}}{z_{0}}\right)}
$$




$$
R_{R}=\eta * 0.5 * A D * \frac{\pi}{4} * R D_{i}^{2} * \sum P_{k} W S_{k, R, h_{i}}^{3}
$$

With the wind strength at the hub height and the technological information of a turbine, the amount of produced energy can be derived using equation (C.2). The efficiency factor of the power plant is given by $\eta$ and set to $36 \% 34$ such that the overall produced energy in 2002 equals the reported produced energy published by the electricity network operators ${ }^{35} \mathrm{AD}$ is the air density at the hub height. It amounts roughly to $1.2 \frac{\mathrm{kg}}{\mathrm{m}}$. RD is the rotor diameter. Finally, WS stands for the wind strength. Since wind strength affects the return of the wind turbine to the power of three, we approximate the wind strength distribution using the mean wind strength and a Rayleigh distribution, which is a good approximation for the wind strength distribution in Western Europe. In a first step the probability to observe a wind strength of $1,2, \ldots, 30$ meter per second $(\mathrm{m} / \mathrm{s})$ is calculated. It is shown for an average wind strength of 5,7 and $9 \mathrm{~m} / \mathrm{s}$ in Figure C.1. Based on the distribution of wind strength in a particular county the amount of produced electricity for each wind turbine is calculated. We further multiply the value per hour with 365 (days) and 24 (hours) to derive the amount per year.

Figure C.2 reports the electricity generated by wind turbines according to our simulation and as published by the network operators for 2000 to 2012 36 Over all the model matches the published data fairly well: Up to 2006 the two lines almost overlap, onwards there are temporary differences.

To derive the stream of revenue for each wind turbine, we determine the feed-in tariff which applies for the year of the connection to the grid ${ }^{37}$ For wind turbines built before the REA was introduced we assume that investors expect to receive

\footnotetext{
${ }^{34}$ In a robustness check we used the wind strength at the 80th percentile and ended up with an efficiency factor of 0.33 . This suggest that our microsimulation is quite accurate as the efficiency factor of wind power plants is between 0.2 and 0.4. The efficiency factor includes the potential breakdown of the plant. Further, it accounts for the fact that plants might not be built at a location with the average wind strength in a county but with a better one. The reader should note that the efficiency factor is different from the capacity factor (ratio of produced to installed capacity) discussed in the literature (e.g. Boccard (2009)). The capacity factor in our study equals the one that can be derived from official publications as our simulation only replicates the aggregated numbers. The efficiency factor we use to calibrate the model is an indicator of how much energy is produced by a particular turbine in relation to the overall kinetic energy available and thus for a given wind strength distribution at a particular location.

${ }^{35}$ The information is included in the REA statements (https://www.netztransparenz.de/de/EEG Jahresabrechnungen.htm). 2002 is chosen randomly, results are similar when using other years to calibrate the simulation.

${ }^{36} \mathrm{In}$ the year of construction we assumed that half of the yearly energy is feed-in.

${ }^{37} \mathrm{We}$ assume that the year of connection to the grid equals the construction year.
} 
Figure C.1: Wind Strength Distribution for Different Means

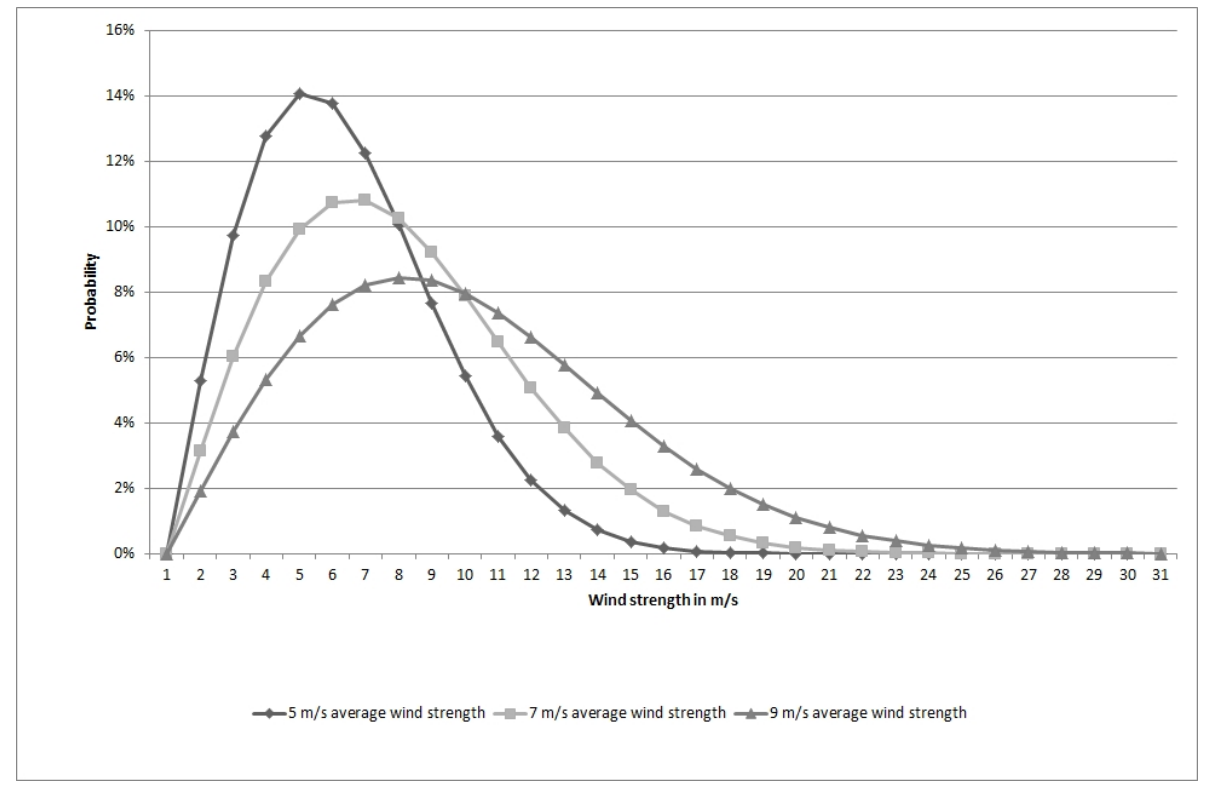

Source: Author's calculations using Rayleigh distribution.

Figure C.2: Produced Energy by Wind Turbines



Notes: Produced energy by wind turbines based on REA statements published by the network operators and based on the simulation model are depicted.

Source: REA statements and authors' calculations based on German Weather Service and operator database 1990-2012. 
the guaranteed price of $90 \%$ of the end-consumer price for three years after the installation of the plant, afterwards we assume that investors expected the average market price for electricity of 3 cent per $\mathrm{kWh}$.

Since the length of the first part of the feed-in tariff under the REA depends on the ratio of the return of the plant to the return of a reference plant defined in the law, we calculated the return of the reference plant using the steps outlined above ${ }^{38}$ The hypothetical reference wind power plant is defined as the same plant at a location with $5.5 \mathrm{~m} / \mathrm{s}$ average wind strength at a height of 30 meter above ground and a roughness parameter of 0.1. Based on the reference plant return, we calculate the years and months the higher first feed-in tariff is paid. After deriving the expected income streams, we simulate the net present value of the future income streams using a discount rate of $3 \%$ and a life span of 20 years.

The costs of each wind power plant are assumed to be 650 euros per installed kW capacity based on the survey by Gasch and Twele (2011). They suggest installation costs to be around 530 euros per $\mathrm{kW}$ and between 15 and $20 \%$ other investment costs, e.g. connection to the grid or baseplate. The investment and related costs are considered by assuming geometric depreciation allowances with a life span of 16 years ${ }^{39}$ Further, we assume a ratio of debt financing of $80 \%$ with a interest rate of $4.5 \%$. The bank loan is paid back in 8 years. All these parameter choices are based on descriptive statistics of balance sheet and profit and loss statements of wind turbine firms in the database DAFNE (see Appendix D). The equity rate of return is assumed to be $3 \%$.

\footnotetext{
${ }^{38}$ The length of the first feed-in tariff is at least 5 years and extended by two months for each 0.75 percent ( 0.85 for the years 2005 to 2008 ) of which the produced energy is below $150 \%$ of the return of the hypothetical reference wind power plant.

${ }^{39}$ This was the life span assumed by the tax authorities.
} 


\section{Appendix - Descriptive Statistics for Wind Tur- bine Firms in DAFNE}

The information on wind turbine firms' depreciation allowances and finance structure are based on descriptive statistics from the DAFNE database. The DAFNE database contains financial statements (mainly balance sheet but for a few firms also income statements) for German firms with a limited liability for the years 2004 to 2012. Since wind turbines at one location are often in single companies and have in most cases limited liability, financial statements are observed for some wind turbine firms. We identify wind turbine firms as follows. In the first stage all firms with wind in their company name are identified. From these firms, firms with operator, real estate, administration, or development in their company name are excluded. To derive an even finer sample, firms with fixed assets of less than 100,000 euros and firms with a standard deviation of the depreciation allowances above 0.1 are excluded. The first requirement is used as already very small wind turbines with only 133 kWh installed capacity have assets of a value of about 100,000 euros. The second requirement ensures that only "one time wind turbines (parks)" are included and not wind turbine parks to which single wind turbines are added in different years as this would not allow to identify the rate of depreciation allowance.

From roughly 30.000 firms with wind in their company name 7.473 are left in the final sample. The number of firms for which the variables of interest are available differ due to data availability. The statistics are shown in Table D.1. They suggest that the rate of depreciation is between 10 and $14 \%$ for about $90 \%$ of all firms in the sample. This is in line with a geometric depreciation with twice the rate of linear depreciation method rate and a life span of 16 years, which was allowed in Germany for tax purposes between 2001 and 2005. Before and after it was three times the linear depreciation method rate.

Regarding firms' financing behaviour, the overall debt ratio that is available for all firms as well as the ratio of bank liabilities to total assets, available only for a subsample, is reported. The reader should note that due to a different life span of fixed asset and the maturity of loans as well as firms' payout policy the initial debt ratio can only be calculated in the first year. The descriptive statistics suggest a range from $77 \%$ to $100 \%$ for the overall debt ratio and from $63 \%$ to $89 \%$ for bank liabilities to total assets. The maturity of debt is similar using overall debt or only bank liabilities and is around 8.5 years. It is calculated using the repayment rates of debt and bank liabilities, respectively. Finally, the interest rate, calculated as 
interest payments divided by overall debt and bank liabilities, respectively, is shown in the last four columns. Regardless of whether payments are scaled by current or lagged values, the median interest rate is around $4.5 \%$.

Table D.1: Descriptive Statistics Wind Turbine Firms

\begin{tabular}{l|cccccc}
\hline & $\mathrm{N}$ & $\mathrm{p} 10$ & $\mathrm{p} 25$ & $\mathrm{p} 50$ & $\mathrm{p} 75$ & $\mathrm{p} 90$ \\
\hline Rate of depreciation allowances in \% & 5,825 & 0.06 & 0.10 & 0.12 & 0.14 & 0.21 \\
Debt ratio (DR) & 7,473 & 0.48 & 0.74 & 0.91 & 0.99 & 1.00 \\
DR year of incorporation & 84 & 0.59 & 0.77 & 0.95 & 1.00 & 1.00 \\
Bank liabilities to total assets (BL) & 1,318 & 0.49 & 0.70 & 0.87 & 0.96 & 0.98 \\
BL year of incorporation & 18 & 0.32 & 0.63 & 0.81 & 0.89 & 0.92 \\
Maturity DR in years & 5,849 & 1.54 & 5.14 & 8.41 & 12.19 & 19.96 \\
Maturity BL in years & 703 & 3.37 & 5.98 & 8.78 & 11.49 & 15.98 \\
Interest to debt in \% & 347 & 1.38 & 3.48 & 4.31 & 5.06 & 5.60 \\
Interest to L.debt in \% & 244 & 1.46 & 3.15 & 3.86 & 4.56 & 5.02 \\
Interest to BL in \% & 287 & 3.55 & 4.30 & 4.92 & 5.69 & 8.74 \\
Interest to to L.BC in \% & 173 & 3.35 & 3.84 & 4.44 & 5.19 & 9.27 \\
\hline
\end{tabular}

Notes: L.stands for last year values. For further information see text.

Source: DAFNE data base, 2004-2012, own calculations. 